\title{
\#globalcitizen: \\ Power, Publics and Popular Culture in the Design of Humanitarian Engagement
}

\author{
by
}

Danielle Leduc

A thesis submitted to the Faculty of Graduate and Postdoctoral Affairs in partial fulfillment of the requirements for the degree of

Master of Arts

in

Political Science

Carleton University

Ottawa, Ontario

(C)2013

Danielle Leduc 
Library and Archives

Canada

Published Heritage

Branch

395 Wellington Street

Ottawa ON K1A ON4

Canada
Bibliothèque et

Archives Canada

Direction du

Patrimoine de l'édition

395 , rue Wellington

Ottawa ON K1A ON4

Canada
Your file Votre référence

ISBN: 978-0-494-94606-0

Our file Notre référence

ISBN: $978-0-494-94606-0$
NOTICE:

The author has granted a nonexclusive license allowing Library and Archives Canada to reproduce, publish, archive, preserve, conserve, communicate to the public by telecommunication or on the Internet, loan, distrbute and sell theses worldwide, for commercial or noncommercial purposes, in microform, paper, electronic and/or any other formats.

The author retains copyright ownership and moral rights in this thesis. Neither the thesis nor substantial extracts from it may be printed or otherwise reproduced without the author's permission.
AVIS:

L'auteur a accordé une licence non exclusive permettant à la Bibliothèque et Archives Canada de reproduire, publier, archiver, sauvegarder, conserver, transmettre au public par télécommunication ou par l'Internet, prêter, distribuer et vendre des thèses partout dans le monde, à des fins commerciales ou autres, sur support microforme, papier, électronique et/ou autres formats.

L'auteur conserve la propriété du droit d'auteur et des droits moraux qui protege cette thèse. $\mathrm{Ni}$ la thèse ni des extraits substantiels de celle-ci ne doivent être imprimés ou autrement reproduits sans son autorisation.
In compliance with the Canadian Privacy Act some supporting forms may have been removed from this thesis.

While these forms may be included in the document page count, their removal does not represent any loss of content from the thesis.
Conformément à la loi canadienne sur la protection de la vie privée, quelques formulaires secondaires ont été enlevés de cette thèse.

Bien que ces formulaires aient inclus dans la pagination, il n'y aura aucun contenu manquant. 



\section{Abstract:}

Humanitarian appeals depend on a process of 'making public', which leaves space for government in the mediums, technologies, texts, visuals and videos that shape address and response and bring human needs into the light of the public. As such, a language of publics illuminates how contemporary interfaces of humanitarian engagement work to grab and hold popular attention. I use the public constructed by the Global Citizen application and festival to argue that while contemporary humanitarian publics embroiled with neoliberal market rationality, brand logic and liberal governmentality hold political and anti-political effects, there has not been a shift from a pure, humanitarian sentiment to one contaminated with self-interest. The self has always been part of humanitarian appeals. Consequently, it is the design of humanitarian engagement, rather than contemporary humanitarianism itself, that circumscribes the emancipatory potential of publics and ignores the potential of design to interrupt the expected and inspire critical action. 


\section{Acknowledgements}

Thank you to William Walters for your keen supervision, this would have been a dubious project without you.

Thank you to Fiona Robinson for spotting the holes in my draft, and to Daiva Stasiulis for teaching the seminar course that would produce the seeds for my third chapter.

Thank you to my parents, Rhonda, Eugene and Lisa, for your loving support throughout my education.

Thanks to my brothers for keeping me competitive.

Thank you to James for your patience, and everything else. 
Abstract

Acknowledgments

Table of Contents

\section{Introduction}

Humanitarian Reason and its Publics $\quad 1$

Research Questions 4

Thesis $\quad 5$

Literature Review 8

Theoretical Foundations $\quad 11$

Methodology 13

Research Implications and Limitations $\quad 14$

Thesis Structure $\quad 15$

\section{Chapter One}

I Was Here: The Enigmatic Self of Humanitarianism 18

Songs of Self and Other, Virtue and Reason 25

Expanding Solidarity from Citizen to World 27

Christian Sympathy and Care $\quad 31$

Liberalism and Progress: Humanitarianism, Remixed 37

Humanitarian Philanthropy: Responding with Money 38

A New Calculation on the Scale of the World 41

Humanitarian Popular Culture $\quad 43$

Conclusion: Why Publics Matter for the \#Humanitarian 46

\section{Chapter Two}

A Gathering Force:

Publicity and Publics in Contemporary Humanitarianism 50

Who is Public? What is Public? 55

A Humanitarian Public 61

Epistemic Claims and the Search for Humanitarian Truth 67

Humanitarian Duty and Popular Professionalism 71

Popular Publics: Humanitarian Virtue for the Masses $\quad 74$

Conclusion: Logics and Their Effects $\quad 76$ 


\section{Chapter Three}

Give me an iPhone and I will Raise the World:

Designing Popular Humanitarian Publics.

Encouraging Global Citizens

Global Citizenship: A Humanitarian Interface 84

Designing Humanitarianism $\quad 88$

The Global Citizen Application as a Tool and Interface 90

Conclusion: The Problem of Design $\quad 99$

Conclusion

New Designs, New Directions

103

Bibliography

107 


\section{Introduction}

\section{Humanitarian Reason and its Publics}

On September 29th, 2012, a massive stage in the shape of a glowing red circle lit up the Great Lawn in New York's Central Park with performances by Canadian hip-hop artist K'naan, and rock bands including the Black Keys, the Foo Fighters, and Neil Young with Crazy Horse. The festival was organized by The Global Poverty Project, an Australian advocacy organization that uses experiential tactics to gain popular attention for humanitarian causes. The organization is most well known for its 'Live Below The Line' campaign, where participants sign up and raise funds in their community to experience the burdens of extreme poverty by living off of less than a dollar and fifty cents (US\$) a day. ${ }^{1}$ The festival in New York was planned as a component of their newest project, 'Global Citizen', an online application where globally-minded, young humanitarians are encouraged to register as 'Global Citizens' and earn 'activist points' and 'advocacy badges' by sharing videos and essays on Facebook and Twitter and signing petitions. ${ }^{2}$ Those who earned at least eleven points during the application's launch phase were entered into a draw to win tickets to

$1<$ https://www.livebelowtheline.com/> accessed 25 February 2012>

$2<$ http://www.globalcitizen.org/> accessed 25 February 2012> 
the Global Citizen festival as a reward for their efforts to advocate for an end to 'extreme poverty'.

The application and its celebratory festival are aimed at building a sustainable movement against 'extreme poverty' that generates funds for partner NGOs and foundations (who provide much of the shareable content), and pressures national governments to increase foreign aid. By encouraging participants to act as agents of publicity for the Global Citizen application, as audience members at the festival, and as conscientious American citizens working to mobilize a force for global justice, the discursive practices of the Global Citizen application and festival blur the boundaries between social movement and festival, between philanthropy and social justice, and between participant and spectator. So how can we understand what is at stake in this new public, in this new way of framing global citizenship?

Whether we register online as a Global Citizen, purchase a Gap t-shirt to donate money for HIV/AIDS, wear a silicone wristband imprinted with the name of a charity, send a dollar a day to World Vision to sponsor a child somewhere far away, or support a military intervention in order to save lives, we are responding to the demands of humanitarian discourse in contemporary politics. Humanitarian discourse demands attention and encourages certain ways of being public and political, for the call to help others when their lives, safety and happiness are at risk requires mediated publicity and action. There is mediation in humanitarian discourse because third party organizations and individuals, such as journalists and celebrities, publicize the suffering and needs of often 
distant others, while popular action to help others becomes synonymous with supporting campaigns or spreading awareness. These campaigns attempt to shape the behavior, beliefs and conscience of the self in their appeals, bringing into being the 'humanitarian self' by telling us what actions we need to take, and telling us what kind of moral subjects we should be. So while medical anthropologist and critical sociologist Dider Fassin (2011) argues that humanitarian reason, or the "deployment of moral sentiments" in politics (p.1), governs the lives of the "precarious" others it aims to help (p. 4), humanitarian reason also governs those who are called upon to support humanitarian causes whether as citizens, consumers, youth, newspaper readers, twitter followers or day-time television watchers. It is this humanitarian self - the target of appeals to aid others, to alleviate suffering in times of crisis and prolonged need - that exposes the many subtle ways in which we are governed. This self of humanitarianism is especially visible with the permeation of humanitarian appeals in popular culture, advertising and social media.

With communication becoming more networked and traceable, increasingly defined by online social worlds and expanding information sources, technology is aiding in the translation of humanitarian appeals for popular audiences in new and important ways. While the LiveAid and BandAid concerts that began in the 1980's attempted to raise awareness and funds for famine and poverty in Africa through music, celebrities, and popular culture, a new generation of initiatives is further embedding humanitarian appeals in social and cultural life through technology. The online and mobile Global Citizen 
application is but one example of the 'tooling' of humanitarian sentiment through social media and mobile technology, in that it provides both the possibility for, and shape of, humanitarian engagement. The problem is that when a political or social body becomes virtualized through online networks that encourage participation as part of spectatorship and consumption as part of production in the circulation of humanitarian appeals, that political body is not quite an audience, a social movement or an interest group. These terms are usually associated with passivity (audience), ${ }^{3}$ self-organization and occupied space (social movement), ${ }^{4}$ and democratic instrumentalism (interest group), but the Global Citizen application blurs the boundaries of these political bodies in its infusion with brand logic, popular culture and self-actualizing social media.

Thus, in order to illuminate the relationship between discursive address and self-recognition in the virtualized political bodies of humanitarian appeals, I venture that a language of publics is better equipped to navigate the politics and power in identifying with, responding to, or even just paying attention to humanitarian causes such as 'extreme poverty'. A public, to Michael Warner (2002), is a self-organized, 'virtual' entity, insofar as its members voluntarily pay attention and respond to the texts, images, and sounds that address them, and insofar as they form a collective public that cannot be considered in separation from this address.

\footnotetext{
3 Sonia Livingstone (2005) defines audiences against publics for this reason, but also argues that the two are not mutually exclusive in contemporary public engagement.

${ }^{4}$ See Manuel Castells' interpretation (2012) of the relationship between occupied space and virtualized networking in contemporary social movements like the Arab Spring.
} 
Because we voluntarily pay attention and engage with humanitarian appeals, and because these appeals are specifically shaped to grab our attention by exposing us to the suffering and needs of others, my thesis examines humanitarian discourse by focusing on the 'self of humanitarian appeals and their publics. The example of the Global Citizen application illustrates the need for scholars to understand the appeals of humanitarian discourse as actively building publics with particular designs of address and designs for response designs that hold both political and anti-political effects. We must ask, according to what logics, technologies, designs and texts is humanitarian reason mobilized not only for the government of those who need help, but also for those who are asked, persuaded and called to as potential supports, potential humanitarian subjects? What is at stake in the publicity and power of humanitarian reason for popular appeal? What is on the line for social justice, global citizenship and the emancipatory potential of publics in our increasingly networked, technological age?

Over the course of three chapters I argue that popular humanitarian appeals and discourses are designed in particular ways to constitute and organize transnational humanitarian publics oriented towards the self through the image of the other. The orientation towards the 'self in humanitarianism, as the moral obligation to aid others in times of need, is not a contemporary phenomenon but contingent on multiple, interwoven historical and social processes. Thinking about humanitarianism as constituting 'publics', as opposed 
to civil societies, communities, social movements, associations, or audiences, is necessary to account for how humanitarian reason is mobilized and articulated through circulatory, diffusive and ever-more technologically mediated designs of engagement that combine and blur the boundaries of these political bodies.

I propose that there are different discursive logics and technical designs through which individuals come to recognize themselves as concerned with and aligned with humanitarian causes, forming popular humanitarian publics. These publics are popular because the address that constitutes them targets a transnational Western society at large, but they are also popular because their campaigns, texts, discourses and technical designs draw on and circulate in popular culture. Yet, it is not the identification with, and attention paid to celebrities, pop music and other ephemera of popular culture alone that give humanitarian appeals their public currency. Embedded in campaigns and appeals are logics by which we are encouraged to identify with and engage in popular humanitarian publics, including the discursive logics of truth or episteme in health and development sciences, and in the calculation and public presentation of humanitarian information. Epistemic claims also blur with the appeals of duty in the humanitarian techne, or craft, of humanitarianism as a vocation, but they hold the most resonance for popular humanitarian publics in shaping the way in which humanitarian crises and concerns enter the public. It is through a process of publicity and truth-telling that epistemic claims accompany bodily condition and personal struggle into the light of the public. Finally, the demand for attention that humanitarian publicity bears does not fully account 
for the power of humanitarian appeals; what is missing is the narrative of humanitarian virtue and self-realization achievable through the aid of others.

These logics of popular humanitarian appeals are articulated in specific ways through the design of technologies, devices, and mediums of communication, information, and emotion. Consequently, humanitarian address and response are designed and made possible by design through different assemblages of logics, mediums of communication, and technologies, leaving the emancipatory potential of humanitarian publics in a precarious state. This is because popular humanitarian publics, like the one convened by the Global Citizen project and the threads of philanthropy, popular culture and humanitarian virtue it draws from, are made by grabbing attention with compelling stories, images, videos and statistics. These things do not come from nowhere, but are written, filmed, calculated and produced by NGOs, journalists, corporations, celebrities, research groups and other humanitarian professionals and organizations. What this means is that there is room for government, as the shaping of beliefs, values, actions and behavior, in the discursive circulation of humanitarian publics and in the design of response.

The popular appeals of humanitarian campaigns provide the focus for this thesis because of the breadth of their address and the multiplicity of logics, techniques and tactics of communication they use. It is through the translation of humanitarianism for popular appeal and mobilization that many of us come into contact with humanitarian discourse, affecting not only how we see the 'other', but how we may see ourselves as political subjects and agents of change. Using 
the Global Citizen application as a case study, I argue that the design of address and response has important political and anti-political effects. The design of this particular application and its discursive appeals link humanitarian subjectivity to capitalist rationality and liberal governmentality under the flag of global citizenship, circumscribing other ways of being humanitarian, of being political, and of being a global citizen. But if these discursive practices do indeed signal new reconfigurations along with certain continuities of the 'self' in popular humanitarianism and publics, as I argue, how can we understand these publics in relation to existing literature that addresses the politics of relationships of giving and solidarity in the popular imaginary?

\section{Literature Review}

For decades, philanthropy as a field of academic inquiry was limited to studies that provided descriptive histories of philanthropic foundations and studies that provided normative assessments over how best to distribute or facilitate donations. Over the last three decades, critical theory provided an impetus for a fresh look at philanthropic humanitarian campaigns through the perspectives of many different disciplines, such as cultural studies, communication studies, women's studies and political sociology. During this time, humanitarianism has become widely perceived as a profitable enterprise for businesses that align with charitable campaigns, spurring a new field of inquiry that includes dissecting the Orientalizing visual culture of popular humanitarian campaigns that are configured according to brand logic (see 
Brough 2012). This field also includes studies on the impact, efficacy and morality of philanthropy, corporate social responsibility, cause marketing, 'consumer philanthropy', 'charitainment', 'commodity activism', 'social entrepreneurship', and the overall melding of humanitarian or social sentiments with capitalist reason and popular culture. Recent publications addressing these topics include marketing professional and writer Mara Einstein's Compassion, INC.: How Corporate America Blurs the Line Between What We Buy, Who We Are, and Those We Help (2012), Roopali Mukherjee and Sarah Banet-Weiser's Commodity Activism: Cultural Resistance in Neoliberal Times (2012); and Micheal Edwards' Small Change: Why Business Won't Save the World (2012), which responds to the assumptions of literature such as Lewis D. Solomon's Tech Billionaires: Reshaping Philanthropy in a Quest for a Better World (2009); and Matthew Bishop and Michael Green's Philanthrocapitalism: How Giving Can Save the World (2009).

Closest to the topic of this thesis is an even more recent work by media scholar Lilie Chouliaraki, titled Ironic Spectator: Solidarity in the Age of PostHumanitarianism. While Chouliaraki argues that the effort to market humanitarian concern through consumerism, spectacle, celebrity culture and technology marks a new age of 'post-humanitarianism' in its turn toward the 'self and the movement from a politics of pity to a 'politics of irony', I argue in the first chapter of this thesis that the 'self has always been intrinsic to humanitarian appeals and discourse. A focus on publics illuminates this relationship. 
Although I draw heavily on Warner's work in Publics and Counterpublics (2002), I also engage with the classic texts of John Dewey (1925), Walter Lippmann (1927), Hannah Arendt (1958) and Nancy Fraser (2007) in outlining what counts as a public and what forms contemporary publics might take, given changing technologies and networks. Lippmann argued that the public is a phantom, in that it is not "a fixed body of individuals. It is merely those persons who are interested in an affair and can affect it only by supporting or opposing the actors" (Lippmann 1946, 77). Dewey postulated that due to social and political changes in the expansion of citizenship, nation and social networks, the public, which regulates the consequences of associated behavior in democratic politics, "seems to be lost; it is certainly bewildered" $(1925,117)$. Jürgen Habermas (1962, translated to English in 1989) later charged that the emancipatory potential of a circulatory, discursive public sphere separate from the state has been compromised by its contemporary infusion with advertising and the market. Responding to what she sees as a nation-centric definition of public engagement and discourse, Nancy Fraser (2007) critiqued Habermas but expanded the assumptions of his circulatory, discursive and democratically emancipatory public sphere to argue that there can be transnational public opinion and transnational publics without a polity defined in relation to a particular sovereign.

The arguments of Lippmann, Dewey, Habermas and Fraser, although challenged in some ways by Warner's conception of the public as an amorphous, 'virtual entity' that is reflexive, self-organized and circulatory, provide threads of 
insight into the limitations and possibilities of the constitution, functions and emancipatory potential of publics. Yet, none of these theorists consider the kind of optimistic public oriented towards global justice that is brought into being and reflected by the discursive practices of the Global Citizen application and festival. To discern the political effects and possibilities embedded in humanitarian publics themselves requires further theoretical grounding.

\section{Theoretical Foundations}

This thesis does not just draw on literature on publics, but also takes a theoretical approach that looks at the small techniques and tools of government. This includes using Michel Foucault's conception of governmentality as the use of mechanisms of power in governance to regulate conduct by producing selfgoverning subjects, to expose the lines of government in appeals to truth, duty and virtue in the articulation of humanitarian reason. But the government of humanitarian appeals does not stop at the production of subjects - my argument also builds on and responds to the field of critical technology studies, specifically Bruno Latour's work (Latour and Weibel 2005) looking at how things, devices, designs, artifacts, mediums and even information itself can be or become political objects. This enables my analysis to consider more networked and circulatory questions of power and governance in the design and dissemination of humanitarian discourse for popular appeal. My argument also attempts to follow Foucault's method of genealogy to make visible not the naturalness or the arbitrariness of the humanitarian appeals that convene particular publics, but 
their "complex interconnection with a multiplicity of historical processes" (Foucault, Questions of Method, 1991).

As a theoretical basis for humanitarian discourse, I heavily engage with Didier Fassin's Humanitarian Reason (2011). Fassin defines humanitarian reason as "the deployment of moral sentiments in contemporary politics" and government (Fassin 2011, 1). He asserts that "humanitarian reason governs precarious lives: the lives of the unemployed and the asylum seekers, the lives of sick immigrants and people with AIDS, the lives of disaster victims and victims of conflict - threatened and forgotten lives that humanitarian government brings into existence by protecting and revealing them" $(2011,4)$. But I intend to expand the scope of his conception of humanitarian reason to the government of those who are asked to support humanitarian appeals and recognize themselves as humanitarian actors. This is the process by which 'the humanitarian' is revealed by illuminating the plight of the 'other' in need of assistance.

Lastly, I engage with Michael Warner's conception of publics to reveal the political effects that designs of humanitarian engagement carry in their reflexive 'world-making' (Warner 2005, p.57). Using Warner's conception of a 'public' as a tool of analysis frames my methodological approach in considering the power of public engagement as a mechanism of governance, the agency of subjects in recognizing themselves as being addressed, and the implications of engaging in a designed infrastructure of response, such as the Global Citizen application. 


\section{Methodology}

Some of the most effective mediums of address today are circulated in social media and popular culture, which are sources of identity in the way they give us "the right to belong and be recognized" (Street, 1997). It is with a focus on these mediums of address and circulation that I analyze the discursive, material and technological designs that constitute popular humanitarian publics through their publicity and demands. Specifically, I analyze the emergence of discursive practices in the public birth of humanitarianism, from Ancient Greece to the networked technologies and multiple logics that constitute humanitarian publics today. This analysis follows a likely line of descent for Western humanitarian thought, due to the case study used.

In my case study I dissect the Global Citizen Festival's official media package, the websites for the Global Citizen Festival and Global Citizen application, the information provided by the application to share in exchange for 'activist points', the Twitter and Facebook pages of the project, and streaming coverage of the Global Citizen Festival. It is in small practices and mechanisms that reflexive subjectivities and their publics can be constituted. Consequently, my thesis is a post-structural, but empirical analysis that starts from the particulars of the emergence of humanitarianism and contemporary humanitarian publics in order to consider larger implications for power, subjectivity, and resistance in a political sociology of modern humanitarian appeals. 


\section{Research Implications and Limitations}

This thesis is not intended to critique blindly the efforts of humanitarian organizations like the Global Poverty Project to mobilize populations, particularly youth, in order to correct severe global injustices. By focusing on the implications of this very visible campaign, I also do not mean to totalize all relevant social justice mobilization as under the shadow of the Global Poverty Project. After all, the Global Citizen Festival drew in more than a million viewers worldwide, but that same week the season opener of the popular ABC sitcom, Modern Family, counted over 14 million viewers. ${ }^{5}$ However, the visibility of, and economic support for, the Global Citizen project and its interactive and rewardsbased approach to mobilization does suggest an emergent reconfiguration of popular threads of humanitarianism, philanthropy, and capital, and it points to the important role technology and its design plays in constituting contemporary publics. This reconfiguration is worth analyzing to consider the trajectory of global citizenship, social movements and publics in a networked, plugged-in age when public space becomes ever-more virtualized and transnational.

The appeals of the Global Citizen App and Festival, articulated through humanitarian sentiment and philanthropic subjectivity, do challenge political apathy and dominant methods of organizing social movements. Yet, the potential for action is co-opted into a tidy, branded package that is nestled in the

5 'Modern Family Open as the \#1 TV Show'. TV by The Numbers. Available at: \{http://tvbythenumbers.zap2it.com/2012/09/27/modern-family-opens-as-the1-tv-show-as-abcs-wednesday-comedy-block-wins-from-8-10pm/150467\}, accessed 07 October 2012\}. 
capitalist, self-aggrandizing interests that perpetuate global injustices. It is here that broader implications of my research lie. This design of public mobilization risks neutering the radical potential of humanitarian publics, global citizenship and social justice amongst the wealthy countries in which the project operates. My thesis thus attempts to fill a gap in the literature on publics, philanthropy, humanitarianism and global citizenship, by both proposing there is value in using a language of publics to frame humanitarian political energy as addressing and governing the 'self', and by analyzing a currently unfolding, emergent public that not only challenges current literature but is also possibly altering the way we see ourselves as agents of change.

\section{Thesis Structure}

The thesis is organized into three chapters. Chapter one argues that humanitarianism has always been tied to the 'self as well as the 'other', so dismissing popular humanitarian appeals as catering to self-interest and selfrealization ignores a more complex understanding of why humanitarian discourse continues to hold resonance in contemporary politics and popular culture. The chapter attempts a brief genealogy of the 'self' in humanitarianism in order to illustrate that perhaps pure altruism is only a subjective guidepost, rather than a truth of humanitarian obligation. This genealogy grounds the second and third chapters in its presentation of a centrifugal realm, rather than static definition, of humanitarianism. 
The second chapter defines publicness, publicity and publics and justifies why a consideration of humanitarian publics is fruitful for analyzing the consequences of humanitarian reason in contemporary politics. I argue that as transnational publics, popular humanitarian publics pose challenges to conceptions of public action that rely on bounded political communities, and to the tensions between attention and action that define public engagement. This is because the particular articulations of humanitarian truth, duty and virtue, through which humanitarian reason is given shape and through which popular humanitarian publics are addressed, carry both political and anti-political effects. An analysis of these logics and effects shows how the transnational, discursive and amorphous qualities of popular humanitarian publics challenge forms of being public that are tied to bounded signifiers like citizenship.

The third chapter looks at what is at stake in a specific popular humanitarian public, taking the Global Citizen application as a case study for analysis because of its recent emergence, its amalgamation of popular trends in humanitarianism and philanthropy, and the questions its public poses for both Warner's conception of publics and Nancy Fraser's assessment (2007) of the transnational public sphere. The chapter argues that through the design of discourse and technologies, the Global Citizen application constitutes a popular humanitarian public dependent upon a discourse of global citizenship that is not simply assembled through a shared belief in virtuous altruism and humanitarian reason, but through the self-evidence of philanthropy, liberal governmentality and a neoliberal capitalist rationality that ties social progress to brand logic and 
market incentives. This frame of global citizenship situates the virtuous Global Citizen as a consumer of branded humanitarianism and an agent of publicity, where each re-tweet and 'share' has the potential to push alternative articulations of global citizenship out of the popular imaginary. So while popular humanitarian publics can potentially motivate the 'self' to identify and respond to the needs of others in an interconnected world of asymmetrical power relations, the address, devices and technologies that inform and enable response must enable and encourage critical discourse and result in diverse ways of being political. This chapter and the thesis conclude to consider what is at stake for not only the emancipatory potential of publics, global citizenship, and social justice, but also for how we can think of the design of humanitarian engagement in modern times. 


\section{Chapter One}

I Was Here?:

The Enigmatic Self of Humanitarianism

Introduction

Pop superstar Beyoncé Knowles walks on stage under the bright spotlights in front of a cheering crowd as the walls and emblem of the United Nations General Assembly hall peel away behind her. Projections onto a floor-toceiling screen set up around the front perimeter of the hall replace the walls with a montage of emotionally jarring humanitarian crises. With this sweeping panorama of disaster and aid behind her, Beyoncé sings:

I wanna leave my footprints on the sands of time Know there is something that, meant something that I left behind When I leave this world, I'll leave no regrets Leave something to remember, so they won't forget

I was here

I lived, I loved

I was here

I did, I've done everything that I wanted

And it was more than I thought it would be I will leave my mark so everyone will know I was here

('I Was Here', Beyoncé Knowles, Columbia Records 2012).

Her performance, produced for the United Nations World Humanitarian Day on August 19, 2012, was released on Youtube and broadcast at the Global Citizen 
Festival in September. ${ }^{6}$ The video describes World Humanitarian Day as "one day, one message, one goal. To inspire people all over the world to do something good, no matter how big or small, for someone else."7 It is a call to altruism, but what is encouraged by the lyrics and spectacular background images of crises is a humanitarian sentiment preoccupied more with personal legacy. Legacy and the cultivation of the self through aid are common narratives in the translation of humanitarian altruism for popular appeal, narratives that are criticized for contaminating the potential of cosmopolitan sentiment for global justice (see Chouliaraki 2013). It may be tempting to categorize 'authentic' or 'pure' humanitarianism as altruism located in an inherent moral impulse to help others less fortunate than oneself in times of need, but humanitarianism is a muddy concept, one that has always been tied to the needs, desires, and beliefs of the 'self.

Academics, journalists, aid workers and others have attempted to give humanitarianism some clarity by separating it from the muck of international politics and defining it as either a neutral procedure or a virtuous ethic. David Forsythe (2009) defines humanitarianism as 'the transnational concern to help persons in exceptional distress' (p. 59), whereas Keith Tester (2010) sees it as 'a moral sensibility demanding action' (p. vii). As a journalist and witness to humanitarian crises, David Rieff (2003) limits humanitarianism to 'the vocation of helping people when they most desperately need help' (p. 27), contrasting

6 The music video, 'I Was Here (World Humanitarian Day Performance)', is available at <http://www.youtube.com/watch?v=i41qW]6QjPI>, accessed 25 February 2013>

7 Ibid. 
with a vision of humanitarianism linked to the shared genealogical roots of the terms 'human' and 'humane'. As Ilana Feldman and Miriam Ticktin (2010) argue, a humanitarianism starting from the ethical status of 'human' results in the "political and social obligations that humans have to each other' making up 'the humanitarian connection" (p. 3). These definitions may be compelling for their perceived moral universalism, but they omit humanitarianism's inherent political history and present. In this respect, Didier Fassin (2010) is perhaps more astute with his approximation of humanitarianism as "both a moral discourse... and a political resource... to justify action considered to be in favor of others exposed to a vital danger, action taken in the name of a shared humanity" (p. 239).

What can be gleaned from this swath of literature is that "humanitarianism is not a timeless truth" (Edkins 2003, p. 254). Instead, humanitarianism can be likened to a genre of shifting ideologies, discourses and practices, much like how similar notes, melodies, or compositional structures are sampled, reused and repurposed in pop music, defying a linear idea of development or evolution. What this analytical frame provides is not just a focus on the ever-mutating compositional substance of humanitarian appeals and practices, but also on how this substance is bound to a history and a genealogy of humanitarianism that holds questions of the 'self and 'other' at its core.

By considering humanitarianism's "complex interconnection with a multiplicity of historical processes" (Foucault, 1991), this chapter attempts to build on Didier Fassin's conception of 'humanitarian reason' as the 'deployment 
of moral sentiments in contemporary politics' $(2011$, p.1), and reframe governance through humanitarianism as also concerned with those who are asked to support humanitarian appeals and recognize themselves as humanitarian subjects. Fassin argues that "humanitarian reason governs precarious lives," such as "the lives of the unemployed and the asylum seekers, the lives of sick immigrants and people with AIDs, the lives of disaster victims and victims of conflict" (p.4), but humanitarian appeals and governance cannot be separated from the publics they address for support. Put differently, Fassin's humanitarian reason may deal primarily in the "threatened and forgotten lives that humanitarian government brings into existence by protecting and revealing them" (p.4), but calls to compassion and aid grounded in a shared humanity also necessarily bring into existence the potential humanitarian subject. So humanitarian appeals govern both 'self and 'other', according to Rose and Miller's definition of governance as "the historically constituted matrix within which are articulated all those dreams, schemes, strategies and maneuvers of authorities that seek to shape the beliefs and conduct of others in desired directions by acting upon their will, their circumstances, or their environment" (Rose \& Miller, 1992). But given the focus on the construction and government of the 'other' in current humanitarian literature, I am concerned with the complex, enigmatic humanitarian self that is brought into being as a subject of government through the designs of popular humanitarian campaigns and initiatives. 
The governance of the humanitarian self cannot be reduced to the mere act of individual interpellation as theorized by Louis Althusser, where all ideology hails or interpellates "concrete individuals as concrete subjects" (Althusser, 1970). This process "can be imagined along the lines of the most commonplace everyday police (or other) hailing: 'Hey, you there!'” (Althusser, 1970). By recognizing we are being addressed, or hailed, we become an "alwaysalready" subject (Althusser, 1970). Although interpellation is a starting point for thinking about the process of recognition in subjectivity, an analysis of humanitarian governance through discourse requires a genealogical and historically situated exploration of humanitarianism as a cloud of moral thought, practices, beliefs, virtues and logics, starting with how humanity, as the basis for humanitarian solidarity and compassion, "appears as both sentiment and threat - an object of care and a source of anxiety" (Feldman and Ticktin 2010, p. 6).

The strain between humanity as both sentiment and threat is just one of the tensions in the history of humanitarianism that destabilizes action grounded in human solidarity, action that wavers "between the egoistic ideal of selfrealization and the altruistic commitment to causes which enables one to 'realise oneself through action" (Boltanski 1999, p. xiv). By situating humanitarianism within a broad web of connected historical processes, this chapter argues that there is space in humanitarian literature to speak about publics as enigmatic bodies of the 'self that defy the easy logic of resistance versus governance, and challenge the boundaries between social movements and consumption, between 
philanthropy and social justice, and among spectator, participant, citizen and activist.

Recent scholarship on humanitarianism tends to focus on humanitarian action as a façade that hides the crude, self-interested maneuvering of international politics, or as an ethical or technical problem that is perfectible, improvable, or inherently unsolvable. Michael Barnett's new book (2011) falls into the latter camp by not only considering the governing qualities of humanitarianism, but also likening the field to an 'empire of humanity', which he argues to be a defining characteristic of the liberal international order. Didier Fassin avoids the impulse to totalize humanitarian reason by situating his analysis of humanitarian reason within particular practices of humanitarian government. But by jumping from a case study of social welfare in France to the construction of AIDS victims in South Africa, he loses the specificity of his genealogy of suffering as rooted in the French sentiments of fraternity, solidarity and rational thought. His case studies are useful, however, for highlighting the inequity of lives that underlies the calculation of risk in aid work, and the small mechanisms of governance in humanitarian testimony shaped to elicit a compassionate response (2011). The normative thrust of his argument is his assertion that we are living in a "new moral economy that values suffering over labor and compassion more than rights" (p. 87), but where subjectivity is analyzed, it is usually limited to that of the precarious life or the humanitarian worker as witness. This is the same for Richard Wilson and Richard Brown (2009), who focus "on the narratives of suffering accompanying humanitarian 
endeavors," including "victims' voices of suffering and their representation" (p. 19).

Recently, however, there has also been a turn towards a recognition that the 'self in humanitarian appeals is inextricable from the 'other', and is thus worthy of analysis in a compassionate 'moral economy'. The turn to the 'self' takes the form of Western vanity in a recent work by Melissa Brough, who questions the narcissism in the visual culture of humanitarianism constructed by the controversial advocacy organization Invisible Children (2012). Fuyuki Kurasawa is another academic who examines the visuality of distant suffering, but he also inadvertently addresses the 'self of humanitarianism and cosmopolitanism in his work that argues for a practice-based conception of global justice (2009a), and humanitarian witness (2009b), recognizing these practices as constitutive of 'ethico-political labor'. Engaging more with popular culture, Lilie Chouliarki questions the emancipatory potential of cosmopolitan sentiment in popular humanitarianism, finding that celebrity humanitarianism and popular humanitarian appeals cast the Western self as an 'ironic spectator' to suffering. She argues that contemporary campaigns steer humanitarianism towards a process of "self-recognition" rather than "other-recognition." Chouliarki identifies this as part of a new era of 'post-humanitarianism', represented by a shift from "unconditional altruism to utilitarian altruism" (Chouliaraki 2011, p. 14). 
In order to interrogate what is public about humanitarianism, and what is at stake in the publicity of humanitarian appeals, this chapter argues that we cannot chart humanitarianism as progressing from 'unconditional altruisim', or the 'authentic', to the 'inauthentic' as sung by a preoccupation with the self by Beyoncé Knowles. Instead, humanitarianism is a muddy concept, a cloud, a genre. Who and what can be called humanitarian has varied throughout time, but contemporary humanitarianism does not represent a natural progression. Rather, the contemporary 'humanitarian' is a remix of the notes and melodies upon which older configurations of virtuous giving or caring were composed, in combination with the newer processes, or songs, of capitalism, consumerism, liberalism and progress in a networked age. The 'self was always there, but it is ever-mutating and enigmatic.

\section{Songs of Self and Other, Virtue and Reason}

Humanitarianism is premised on an idea of humanity as a shared moral community, where each person, by virtue of being, is afforded equal value and respect. For Adam Smith, the "problem of ethics" was a "problem of imagination" (Forsythe 2009, p. 79), which perhaps explains in part how humanitarianism has come to represent "a powerful social imaginary of our time" (Fassin 2011, p. 247). Imagining one's moral community to extend to different and distant others is essential to the humanitarian call, but Richard Rorty argues against rationalist accounts of cosmopolitan humanism that identify others as abstract individuals with a shared capacity for reason. Instead, he claims we need 'sentimental 
education' through narratives of suffering to "generate fellow feelings" (Laqueur 2009, p. 31). For Rorty, sympathy could be "the best weapon we have" (Rorty 1993, p. 130). Humanitarian campaigns attempt to harness this weapon, and what some consider an altruistic impulse, or "a focus on the kindly desire to end misery and suffering," that is "spontaneous and has its own beauty: when giving is unregulated, it becomes deeply moving, an act of freedom" (Borstein, 2009). Indeed, altruism is even thought of as a "natural expression of democratic life" (Gross, 2003). The acts of sympathizing, giving and caring for others in a widened moral community may appear to be self-evident truths or virtues of our times, but they are tied up in specific historical developments.

What follows is a brief genealogical outline of how compassion for the suffering of distant others in a moral community that encompasses all of humanity came to be a guidepost and logic of modern life and contemporary politics. I cannot attempt a full genealogy in the space of this chapter, but it is worth noting that the task of the political or social genealogist can never be complete; there will always be gaps, holes or guesses along the lines of descent. What I venture to do here is to provide a trace of the emergence of the sentiments, actions and rationales that are bound up and remixed in contemporary, Western humanitarian appeals to the 'self'.

Most histories of humanitarianism start from, or at least reference, the revelation of Jean Henri Dunant, a Swiss businessman who came upon the carnage of the French and Austro-Hungarian war in the Italian village of Solferino. A witness to the battle, Dunant later wrote $A$ Memory of Solferino 
(1862), calling for a recognition of "the moral sense of the importance of human life" and to encourage "a positive craving to relieve as many as one can" in the battlefield. The book became a veritable bestseller, and Dunant went on to form the International Committee of the Red Cross with other newly minted 'humanitarians' (Barrett, 2011). Dunant is seen by some academics as the father of modern humanitarianism, which began with a call to ease the suffering of politicized bodies of war. Although these same humanitarian histories also trace the articulation of a common humanity to the discursive appeals of the antislavery movement of the mid 1800s (see Lacquer), a genealogy of humanitarianism stretches farther and wider than this dominant history.

\section{Expanding Solidarity From Citizen to World}

In considering the moral genealogy of the welfare state, Mitchell Dean (1999) examines the ancient Greek notion of euergeisa, the "desire to do good for the city." Dean argues that both euergeisa and Christian pastoral care are ancestral ethical foundations for the modern relation between city and citizen in social liberalism. Yet, Dean finds no "modern equivalent" of euergetism as the twentieth-century term for the "obligation of the ruling nobles to stand as benefactors of their cities," except for perhaps "a partial exception" in the practices of modern philanthropic foundations (p. 93). What defined euergetism in ancient Greece is how virtuous nobles "competed with each other in displays of ostentation and civic duty. They did so to confirm their luminary status, to receive acclaim, applause and titles, and to be remembered through inscriptions 
on headstones and statues as well as by the permanent foundations they established, as generous and noble men" (p. 95). In other words, euergetism was the act of achieving political and personal status and legacy, or the affirmation that 'I was here.' Although euergetism cannot simply be 'applied' to understand the humanitarian virtue of responding to the suffering of others in the present, it has the potential to illustrate certain continuities while revealing important new configurations in how the self of humanitarianism is imagined and oriented in the global North.

The aim of the euergetai, or "those who engage in acts of civic beneficence" (p. 93), was "the nourishment of the city by doing good for it and in so doing to establish oneself as a noble and memorable being" (p. 95). Dean comments that it was an aristocracy based on deeds, rather than blood, and grounded on a feeling of "hardened solidarity" with fellow citizens "rather than feeling of pity or charity" $(1999,78)$. Euergetism is described in this way by Paul Veyne as "private munificence for public benefit" (Cornell \& Lomas 2002, p. 1), making it appear to be an act of compensation for the inequalities of wealth in ancient Greek city-states (Dean 1999, p. 93). But Veyne argues against reducing it "through some kind of functional theory," and instead argues that the nobility practiced euergetism fundamentally as an expression of "social superiority" or "political honor" (Swedberg, 1992).

The public act of giving was reconfigured in the economically flush Roman empire to "win hearts and minds, to gain prestige among the plebs, to extend their networks of influence and dependence (clientship), and for their 
own glorification" (Dean 1999, p. 94). But the moral community and solidarity expressed in euergetism did not even stretch to the city's boundaries, for those who benefited from the public gifts "were the citizenry, those who belonged to the demos, by virtue of coming from a citizen family and being a member of a recognized civic group" (p. 95). Public gifts were not charity, but for shared public use that included, and in most cases privileged, nobility, as in the case of forums and structures for entertainment and government (Veyne 1990). Thus, euergetism was not aimed at easing the suffering of others. Indeed, there was no concept of 'the poor,' the downtrodden, or the destitute as a pitiable moral status (Swedberg, 1991). So instead of providing a uniting frame for obligation to others, the city itself was the "object of civic obligation" (Isin \& Lefebvre 2005, p. 10), making euergetism unique for its gifts of "edifices and pleasure to the citizens rather than alms to the poor" (Veyne 1990, p. 21). Although euergetism was not fueled by the kind of compassionate sentiment that grounds humanitarianism, nor did it speak to the emergence of a widened moral community, it marked a climate of self-actualization through public giving and a relation between benefactor and a massified beneficiary that is not structured by pity. What would bring about a challenge to the restrictive moral community of the demos in Greek city-states was not a sentimental education, but the disaggregation of man and polis.

According to the dominant historical record, Diogenes the Cynic in Greek antiquity was the first to say, when asked where he was from, that he was a kosmopolites, or a 'citizen of the world' (Brown 2000, p. 8). This is a metaphor 
for an allegiance with all humanity as fellow citizens, but it is a proclamation that is historically rooted, for he was speaking in a time when the degradation of the city-state challenged the definition of civilized man as necessarily a member of a polis (Brown 2000, p. 8). Diogenes was thus not attacking ethical provinciality, but the Greek habitus of tying personhood to citizenship in the demos. The Stoics later elaborated on the cosmopolitan idea by situating the world citizen within "a series of concentric circles" that define one's identity, relations and obligations, starting with a circle traced around the individual, to the family, moving out to the immediate community and eventually the world (Nussbaum 1998, p. 60). Thus, being a 'citizen of the world' for the Stoics did not preclude the abandonment of one's local positionality and affiliations. Cosmopolitanism, an 'enlightened' value system that extends moral status to all human beings in a shared world order, was later reinvigorated in the $18^{\text {th }}$ century with a new batch of moral theorists, most notably Immanuel Kant, whose universalizing discourse was made possible by the circulation of printed texts, rather than one's direct relations to others in a polis (Habermas 1962). Kant's vision of cosmopolitan world citizenship was premised on the value of reason and held a universal 'kingdom of ends' at its center. This 'kingdom of ends' would be a state of equal status of personhood and ethical obligations to others, regardless of proximity, as a precondition for a 'perpetual peace' (Linklater, 1998). From Diogenes to Kant, cosmopolitanism and world citizenship have been mutually constituted to appeal to a higher moral order for human organization according to the need to recognize the 'other', rather than according to a sentimental sympathy for the 
pitiable condition of others. It is impossible to understand the underlying moral argument of the enlightened cosmopolitanism of humanitarian appeals without the interjection of Christian thought, which did cast the destitute 'other' as a moral category.

\section{Christian Sympathy and Care}

The Swiss businessman who had a hand in the creation of the ICRC, Henri Dunant, was an evangelical Christian, "who saw himself as 'an instrument of god'" (Barnett 2011, p. 79). The anti-slavery movement also owed much of its rhetorical thrust to Christian love and charity, represented by one of the movement's popular slogans: 'Am I not a man and a brother?' There are other religious traditions and groups, such as the international Ismaili Muslim community, that run humanitarian organizations and speak to a humanitarian ethos of helping others, but the European and North American history of Christianity is of particular interest for the development of the sentiment and reason behind seemingly self-evident humanitarian appeals.

In his lecture series titled Security, Territory, Population, Michel Foucault charts the origins of a particular power of governance in the religions of the "Mediterranean east" brought to "the Western world by way of the Christian church" (Foucault, 2007). As a "power of care," pastoral power originates from scriptures and religiosities that position God as a shepherd of men (p. 124), and consequently those who represent God on earth, Kings and religious officials, are 
shepherds themselves. Pastoral power is a form of power defined by the beneficent sacrifice of the shepherd for the salvation of the flock, for "the shepherd directs all his care towards others and never towards himself" (p. 128). In the requirement to "keep one eye on all, one eye on each" (p. 128), pastoral power totalizes the flock as it individualizes, and frames those who are governed in a position of complete subordination to the shepherd (p. 175). Its raison d'être is "doing good, in order to do good" (p.125), so it is a "bad shepherd" who "only thinks of good pasture for his own profit, for fattening the flock that he will be able to sell and scatter" (p. 128).

Foucault goes on to consider the development of pastoral power in rationalities of governance, but it is in pastoral power that the origins of Christian charity emerge. Robert A. Gross, in his analysis of the evolution of charity and philanthropy in America, defines charity as "a complex of ideas and practices rooted in Christianity," particularly Protestantism, "later reinforced by the heritage of Catholicism and Judaism brought by immigrants in the nineteenth and twentieth centuries" (Gross, 2003). America is of particular interest in the emergence of Christian charity, and its later link to philanthropy, because of the ideals of individualism and self-improvement that emerged in settlement and the American Revolution (p. 40).

Puritan John Winthrop's 1630 sermon, later titled “A Model Of Christian Charity," speaks to the continuation of forms of pastoral power, alongside humanitarian reason, in the emergence of charity in America. Winthrop frames wealth inequalities as inevitable and codified by God, thereby charity, whether 
money, aid, or advice, is required to live in harmony (Winthrop, 1630). Humanitarian reason, as the naturalized appeal to the common value of all human life, is approximated in the call that "every man afford his help to another in every want or distress," but traces of pastoral power are evident in his appeal to "let him lay aside as God hath blessed him," which identifies all men as within one flock guided by God (Winthrop, 1630). This pastoral call points to the need for self-sacrifice for the benefit of the flock. Winthrop also decries the hedonism and self-interest of the bad shepherd, for "if our hearts shall turn away, so that we will not obey, but shall be seduced, and worship other Gods, our pleasure and profits, and serve them... we shall surely perish" (Winthrop, 1630).

Winthrop's sermon invokes the specter of the Good Samaritan that haunts Western language of humanitarianism and compassionate action. Today, it is invoked in law (Good Samaritan acts) and in public discourse without mention of its Christian roots. The parable of the Good Samaritan is told by Jesus, according to Luke, to explain how to "love they neighbor as yourself" (Luke 10:27). The Samaritan, a minority Muslim man, comes across a destitute victim of a robbery on the side of the road from Jerusalem to Jericho. While two Christian holy men had passed by, the Samaritan "took pity on him", stopped to bandage his wounds and took him to an inn, where he promised the innkeeper to cover the expenses of his care (Luke 10:36). It is a parable of pastoral power that casts the 'other' - the Muslim Samaritan - as morally virtuous in his pity and mercy, while it is careful to describe the injured and destitute man as innocent in his position. 
The evangelical protestant movement of the $17^{\text {th }}$ and $18^{\text {th }}$ centuries carried with it the missionary premise "that individuals possessed free will," and could thus "choose to be saved, shifting salvation from God in the individual" (Barnett 2011, p. 53). Protestant evangelicalism and the greater Christian revivalist movements would be instrumental in the emergence of the pastoral salvation discourse that undergirds humanitarian history and thought, but the concept of moral choice also emerged in secular European and American societies at this time.

In the late eighteenth century, a "devotion to benevolence" was felt amongst the upper classes (Gross, 2003), spurred by enlightenment thinkers such as Immanuel Kant. Kant's 'kingdom of ends', "amounted to a secularizing of the Christian doctrine of universal brotherhood," whereby "respect between rational agents and against the domination of one human being by another" expressed a new ideal for modern morality (Wilson \& Brown 2009, p. 2). For the enlightened upper classes, charity was not a religious obligation as taught by Winthrop, but "part of a transcendent realm of moral choice," representing "new modes of domination" (Kidd 1996, p. 188). Adam Smith wrote $A$ Theory of Moral Sentiments during this time, opining that however selfish man may be, "there are evidently some principles in his nature, which interest him in the fortune of others, and render their happiness necessary to him, though he derives nothing from it except the pleasure of feeling it" (Smith, 1875). His writing did not just point to a compassionate impulse, but also shows the transfer of pastoral power in the care of others from God to the common man. Although charitable giving 
was still an unstructured and often individual activity, symbolized by the act of helping the beggar at the door, the same enlightenment ideas of universality, fraternity and solidarity were at work elsewhere, most notably in the French Revolution (Barnett 2011), a violent mobilization of compassion that, centuries later, spurred Hannah Arendt to denounce a 'politics of pity' that privilege sentiment and suffering over justice (Arendt 1963).

The question of sympathy in public discourse was again put to the test with the organization of antislavery sentiment beginning in the mid nineteenth century, a time when humanitarian appeals proliferated. Thomas Laqueur argues that humanitarian sentiment was shaped during this period in a relationship with death, where the specter of dying unmarked and unacclaimed contributed to a belief in the value of being human in itself, as a kind of neurotic remedy for death (Laqueur 2009). But the recognition of a common humanity operates on multiple levels of discourse for Laqueur. These include the 'biological human', where the suffering of bodies as a "physiological fact" is premised in humanitarian appeals, such as in drawings and testimonies of the extreme physical strain and threat of death on slave ships (2009). But the human is also cast as an "ethical subject", whereby "antislavery texts demand insistently that we see these bodies embedded in exactly the sort of nexus of social relations as those of their readers and auditors" (p. 42). It is a process of 'slow seeing' (p. 40) that must have been quite slow, indeed, for despite the popular success of the abolition movement, European colonial discourse continued to bathe in the untroubled waters of paternalistic beneficence and racist politics. 
This is where the popular history of humanitarianism begins, rife in the contradictions of European and American politics, premised on the recent, virtuous rise of public, secular compassion, and overshadowed by Christian imperatives. The non-governmental organizations of the twentieth century, ideologically styled after the International Committee of the Red Cross, held faith in a vision of humanitarianism that is neutral, apolitical, and impartial in its mission to ease and ameliorate the suffering of distant others (Rieff 2003). Whether through the narrative of Save the Children, which attempts to "unite around the idea of the innocence of the child and agree that children are the building blocks for a better future," or the technical language of the United Nations High Commission for Refugees, which demarcates 'refugees' from 'internally displaced peoples' (Barnett 2011, p.86, p. 171), humanitarian reason became a mobilizing logic of governance to reveal the precarious lives of others. But humanitarian appeals are not reducible to an Arendtian 'politics of pity' that "regard the misfortunate together en masse" (Boltanski 1999, p. 5). Such an account does not properly consider the muddy qualities of humanitarian appeals, nor does it take into account the other complex modalities and logics of government and the 'social economy' (Procacci 1991) that would become tighter circuits to the centrifuge of humanitarianism in the later half of the twentieth century. We can see traces of these circuits in article 22 of the League of Nations Covenant, which hums an ominous tune in its proclamation that for "colonies and territories... inhabited by peoples not yet able to stand by themselves under 
the strenuous conditions of the modern world, there should be applied the principle that the well-being and development of such peoples form a sacred trust of civilization" (Barnett 2011, p. 74).

\section{Liberalism and Progress: Humanitarianism, Remixed}

The twentieth century saw a reconfiguration in the humanitarian ideal of a neutral, impartial and apolitical response to suffering. When the United Nation's declared the 1960s the "Decade of Development," it was in vogue with humanitarian organizations such as Oxfam who were slowly recalculating their mandates to at least partially refocus humanitarian action from suffering itself to the causes of suffering (Barnett, 2009). For Oxfam, this meant shifting from a campaign dependent on famine relief to one aimed at the very causes of hunger (p. 110). Human suffering became an undesirable moral object capable of not just alleviation, but elimination (Suski 2009, p. 211). By incorporating developmentalism in the humanitarian project, organizations, institutions and states were inscribing 'the good life' with the virtues of liberal democracy, which include the "highly invasive project of 'liberal peace building"" (Barnett 2011, p. 166), the genealogy of a liberal model of 'good governance', and freedom and rights-based approaches to satisfying human needs. Thus the expansion from "symptoms to root cause" peeled away the façade of humanitarianism as implicitly apolitical, and created "a more centralized network" of humanitarian 
players (p. 168) working towards a liberal order premised on justice, equality and peace. For Barry Hindess, it is in this transformation that "the great liberal project of human improvement has been displayed by - or more precisely, relabeled as - the hardly less patronizing project of human development," for the very foundations of liberal political reason demarcates "between settings inhabited largely by those who can be treated as autonomous agents and settings that are not of this kind" (Hindess 2001, p. 108).

It was in reaction to the 'politicization' of humanitarianism in Iraq by the American government that Medecins Sans Frontiers withdrew from Iraq in 2004 as an act of criticism (Fassin 2011). But this shift away from neutral humanitarianism embodied by the politically-charged actions of the MSF is what prompted David Rieff (2003) to accuse humanitarianism of being "in crisis," for the neutrality of humanitarian organizations is precisely what had enabled much humanitarian work in conflict zones over the previous century. Yet, the movement to professionalize and perfect humanitarianism by both focusing on root causes and viewing "politics as technique" (Barnett 2011, p. 213), cannot be understood without attention to other circuits in the centrifuge of humanitarianism, those of capitalism, neoliberalism and philanthropy.

\section{Humanitarian Philanthropy: Responding with Money}

Running parallel and joining paths with the amalgam of sentiments, virtues and reason that can be called 'humanitarianism' was the emergence of philanthropy. Philanthropy originates from a Greek word for "love of humanity" 
(Holmes, 2012); however, the emergence of the sedimentation of contemporary philanthropy occurs not in linguistic definition, but in the interstice of "a particular state of forces" (Foucault, 1998). Alan Kidd, in his "historiography of philanthropy in all cultures," paints philanthropy as characterized by a gift relationship "governed by values preceding (and conceived of as alternative to) those of the market" (1996, p. 183), yet a history of philanthropy is not simply a "history of kindness" (p. 181). Contemporary philanthropy is identified in contrast to charity and humanitarianism by the method of alms giving and problem solving employed by large philanthropic organizations (Gross, 2003). As such, the 'identity categories' of philanthropy, charity, and altruism are "in fact the effects of institutions, practices, discourses, with multiple and diffuse points of origin" (Colwell, 1997).

With the unfolding of the industrial revolution in Europe and America, came the structuring of charitable giving. London's Foundling Hospital, erected in 1739 , was one of the first institutions oriented towards the care of the worse off for the public good, as a result of the recognition at the time that "England's growth required an expanding population of 'useful hands' and 'good and faithful servants"' (Gross 2003, p. 37). This discourse connecting the public good with charity upholds the trend of pastoral power as possessed by men, specifically men recognized as a "new breed of experts" called 'political economists' (p. 37). The emerging political economists mobilized charitable giving as governance by "urging a redirection of charity to produce a sober, 
industrious, self-reliant working class" (p. 37). Thus, the public good began to be defined in opposition to moral degeneracy.

The 'Victorian moral reformer' continued the ethical trend, with a preoccupation for individual moral progress and giving only to the "deserving poor" (Kidd, 1996). Alan Kidd argues this era of Victorian charity framed giving as a selfless act, but giving was actually "made dependent upon the return 'gift' expected from the recipient, the status of being deserving" (p. 187). A charitable reputation, thanks to local newspapers, also counted as a 'return gift,' which expanded the 'gift relationship' to include the community as the recipient, akin to euergetism, and "in return, the community confers status on the great and good among the benevolent" (p. 189).

With new associations and institutions beginning to structure charitable giving, a "rising commercial ethos" reduced charity to organized alms giving (Gross, 2003), casting personal acts of charity as indiscriminate, unregimented gifts that perpetuate dependence among the poor (Valverde 1991, p. 19). The economization and specialization of charity was the first move towards contemporary philanthropy. During the nineteenth and early twentieth centuries, philanthropy emerged out of charity, aspiring "not so much to aid individuals but reform society," by applying "reason to the solution of social ills and needs" (p. 33). This aim went hand in hand with the emerging American discourse on poverty, identified by Katz as the product of a "culture of capitalism" that measures people by "their ability to produce wealth and their success in earning it" (Loseke, 1997). Philanthropy was thus defined by the large 
foundations of John D. Rockefeller and Andrew Carnegie, with the latter arguing that "the profits of capitalism should be directed to social goals, stewarded by the wealthy, to create large-scale change to solve the problems within society which other parts of capitalism had yet to reach" (Holmes, 2012). Indeed, the original statement of purpose of the Rockefeller Foundation, formed in 1913, was not oriented towards localized social ills, but a humanitarian sentiment "to promote the well-being of mankind throughout the world". ${ }^{8}$ Although acts of charity and humanitarian organization were not by any means superseded by the emerging discourse of philanthropy, the new philanthropic institutions and foundations "reduced charity to a token act," for "now an individual could contribute funds to a house of industry for the poor or to a refuge for unwed mothers, secure that he or she would never come into contact with any of the inmates" (Gross, 2003). This began the sedimentation of the rationalized, structured and impersonal act of philanthropy as a natural inclination or truth of beneficence and operationalization of humanitarianism, which was further codified by capitalism and neoliberalism.

\section{A New Calculation on the Scale of the World}

In the discourse of the Rockefeller and Carnegie foundations there is "a new form of global rationality... a new calculation on the scale of the world" (Foucault, 2008) that was not part of the rationality of Christian charity or

\footnotetext{
${ }^{8}$ Rockefeller Foundation, "Moments in Time": http://www.rockefellerfoundation.org/who-weare/our-history/1913-1919/
} 
eighteenth century humanitarianism. Science was now on the humanitarian's side (Barnett 2011, p. 130), something that would become evident with the adoption of neoliberal orthodoxy in the 1980s, when humanitarian organizations began to streamline and evaluate the efficacy and efficiency of actions according to principles of public management embedded in market logic (p. 215). But in philanthropy, a neoliberal, "strictly economic interpretation of a whole domain previously thought to be non-economic" (p. 219), combines with the logic of humanitarian reason.

Foucault identifies biopower as the "set of mechanisms through which the basic biological features of the human species became the object of a political strategy," and the population appears "above all as the final end of government" (Foucault, 2007). Linking alms giving with the greater public good of collective progress constitutes a biopolitical truth discourse of the "vital character of living humans," that creates modes of subjectification in which individuals, as human capital, "work on themselves in the name of individual or collective life or health" (Rabinow \& Rose, 2006). No humanitarian narrative is more adept at this subjective frame than those campaigns that situate the potential of the 'poor child" as representative of "personal and national development" (Suski 2009, p. 205). It is in this process of subjectivication that the humanitarian appeals of philanthropy are embedded in liberal and capitalist systems of thought, and hold a common thread "running from Adam Smith through Carnegie and Rockefeller to Warren Buffet which argues that those who gain most from enterprise should steward this wealth for the greater benefit of humanity" (Holmes, 2012). Yet, it 
is not only the wealthy that are called upon as humanitarian subjects through philanthropic appeals. Indeed, the common humanitarian in contemporary popular discourse is not the classic philanthropist or aid worker, but the everyday citizen and consumer who has had "no physically immediate encounter with necessity of the needy" (Tester 2010, p. 7) and has no foundations in her name.

\section{Humanitarian Popular Culture}

Like humanitarianism, contemporary philanthropy is centrifugal, which means that "new elements are constantly being integrated" in a way that "involves organizing, or anyway allowing the development of ever-wider circuits (Foucault 2007, p. 45). Consequently, contemporary philanthropy may contain a combination of historical traces, including links to pastoralism, humanitarian reason, Christian charity, and neoliberal calculations of the public good, but since the creation of the first large-scale philanthropic organizations, the practices of philanthropy have been reformulated and expanded to incorporate new rationalities. One notable reformulation is the transformation of humanitarians from volunteers or aid workers, and the philanthropist from "profitable corporations or rich individuals" (Holmes, 2012) to average citizens and consumers through the incorporation of philanthropic practices and humanitarian discourse in popular culture. Popular culture and celebrity representations constitute the public domains of liberal democracies, which "construct and structure the character and meaning of public life" through 
"profound appearance and performance" (Yrjola, 2011). In this performance we see a return to the 'feudal' features of publicity according to Habermas, when "publicity imitates the kind of aura proper to... personal prestige and supranatural authority," and when publicity is about representing oneself and one's own position in a "display of showy pomp before customers ready to follow" (Habermas 1962, p. 195) However, popular culture is also a site and location of politics, where dissidence is not made impossible by representative publicity, only complicated by it.

Liberal popular culture and celebrity culture in the 1980 s reformulated philanthropy as a networked, populist practice, illustrating the tensions between representative publicity and critical politics. When the BBC aired a documentary on the Ethiopian conflict and famine in 1984, the famine was barely on the popular radar. Combining graphic imagery of suffering Ethiopian children along with commentary that "spoke in religious terms to describe the horror" (Barnett 2011, p. 156), the documentary caught the attention of singer and music producer Bob Geldolf. Geldolf was inspired to take action, organizing the massive Band Aid and Live Aid concerts of the 1980s. An original song written in response to the situation in Ethiopia by Micheal Jackson and Lionel Richie, titled 'We are the World', hit the pop charts, successfully "raising millions of dollars for famine relief and providing a soundtrack for the dying" (p. 156). The Band Aid and Live Aid festival concerts, broadcast all over the world, gathered together celebrity musicians to chant another popular song penned by Bob Geldolf and Midge Ure: 
It's Christmas time, there's no need to be afraid

At Christmas time, we let in light and we banish the shade

And in our world of plenty, we can spread a smile of joy

Throw your arms around the world at Christmas time

...Well tonight thank god it's them instead of you

And there won't be snow in Africa this Christmas time

The greatest gift they'll get this year is life

Where nothing ever grows

No rain or rivers flow

Do they know it's Christmas time at all?

Here's to you, Raise your glass for everyone

Here's to them, Underneath that burning sun

Do they know it's Christmas time at all?

Feed the world!

(“Do They Know it's Christmas Time?: Bob Geldolf and Midge Ure, 1984)

Band Aid and Live Aid, staged to raise funds for a famine in Ethiopia, speak to the importance in recognizing pop culture and celebrities as a "crucial site of politics" (Yrjola, 2011). Songs like 'Do They Know its Christmas Time' and 'We are the World" present an "ideal identity for the spectator as a citizen of the world" (Chouliaraki 2006, p. 2), through a racialized pastoralism, where a "revolution of global concern" (Rieff 2003) casts the Western humanitarian subject as the shepherd empowered to lead a flock of multiethnic, vulnerable others through humanitarian action as a spectator, citizen and consumer. This narrative promotes a supposedly apolitical antiracism, where the world is imagined and celebrated as a mosaic of nations with global citizens, usually communicated through childhood innocence and images of children divorced from any context (Malkki 2010, p. 59). 
For David Rieff, the narratives and testimonies of tragedy in events like LiveAid "have not lost their power to shock, but they have become familiar, almost as if they were scripted" (2003, p. 38), which they are. This is because humanitarian appeals have not just entered popular culture, but they have become a part of it, whether as calls to purchase ethical products so as assuage the guilt of consumerism, or as festivals and star-studded telethons to aid distant victims of disaster and conflict. Compassion, sympathy and aid have become part of the "dominant moral order of modernity," (Chouliaraki 2011, p. 2). But where Chouliaraki argues this speaks to a kind of 'post-humanitarianism' or, borrowing from Kenneth Cmiel, 'post-populism', in that politics is penetrated and directed by an "elite group of activists" (p. 14), I argue that there is no linear shift in humanitarianism. Instead, popular humanitarianism is merely widening the circuits, including publics in new and transformative ways. So while Chouliaraki insists that contemporary humanitarian appeals reference the 'self' at the expense of the 'other', moving from a politics of pure altruism to altruism contaminated by self-interest, I argue that humanitarianism has always included appeals to the self, and thus was never consistent with a pure, natural altruistic impulse. Contemporary appeals merely privilege the self in more insidious ways.

Conclusion: Why Publics Matter for the \#Humanitarian

The 'self' in humanitarianism cannot be reduced to a member of an audience, or a spectator. Stories and narratives address people, and constitute 
publics in their address. Stories, like songs, cannot be isolated from those to whom they are told or sung, especially when they are communicated to inspire action through the recognition of oneself. Michael Warner, in his remarkable work, Publics and Counterpublics (2004), defines a public as an amorphous mass that is made a target of reflexive discourse, with addressees 'always-already' subjectively constituted as publics. A public, to Warner, is self-organized insofar as its members voluntarily participate, but a public is inseparable from the discourse that is addressed to them. What is interesting about popular humanitarian appeals of the last two decades is not that there is a new 'self that is taking precedence in calls to compassion and altruism, but that the enigmatic self visible in rationalities of giving, caring and sympathetic action from euergetism through to Live Aid is assembling new kinds of publics. It is partially through new technologies and emergent forms of organization that utilize these technologies that the humanitarian self is addressed by a new sample and remix of familiar humanitarian songs. Chief among these is how interactive media are enabling actions outside of 'paying' or 'speaking' (Chouliaraki 2011).

The design of interactive media blurs the "traditional boundaries between work and leisure, education and entertainment, domestic and civic, local and global" (Livingstone 2005, p. 9). The public and the self become increasingly mediated, with publics "moving ever closer to audiences," and creating the 'citizen-viewer'. The individual is also constituted through online self-mediation (Chouliaraki 2010, p. 227), where one's identity is typed, pasted, posted, shared and 'liked' into being. As Lilie Chouliaraki argues, "such 
textualities do not simply represent pre-existing selves, individual or collective, but constitute such selves in the very process of representing them" $(2010, p$. 229). The digital citizen is thus brought into being through networked selfmediation, as a result of the design of the online interfaces that allow for expression and participation in social and political life. This expression is not encompassed by traditional practices of citizenship like voting, and as such, online self-mediation "authorizes traditionally marginal practices, such as blogging or jamming, as legitimate practices of publicity" (p. 227).

This networked, online public changes the spatiality of civic action, where activists can "call for joint, global demonstrations in a network of local spaces in simultaneous time," and political action starting in specific contexts becomes global through connections across the world (Castells 2012, p. 223). The network is "always-on, always-accessible," "linking specific locales to a global continuum and thereby transforming our sense of proximity and distance" (Varnelis 2012, p. 15). As Manuel Castells argues, this is fundamentally changing the dynamics of social movements and civic action, which has implications for what we call citizenship and activism in our networked 'cosmos'.

The movements that Manuel Castells (2012) analyses take place all over the globe, from the Arab Spring to Occupy Wall Street, but while they start online, these networked social movements remain rooted in occupied urban spaces. This peculiar spatiality connecting the local to the global, or to the intangible - the everywhere - is unique to the technologies and networks of the historical moment. Yet, Castells analyzes only those 'movements' that express 
themselves as social movements identifiable through the traditional occupation of concrete space and the articulation of self-organized demands.

With public space becoming "increasingly privatized and virtualized" (Varnelis 2012, p. 18) through globalization, technological advancement and neoliberal rationality, there is the possibility that social movements are blurring with audiences, with publics and with consumption. But what these technologies and new popular narratives do not do is create the 'self. The 'self of humanitarianism was always there - changing, shifting, taking on new forms and leaving others - according to specific historical processes. So while we now have a hashtag and pop songs calling to the humanitarian self, there are a whole range of other logics, tools and mediums through which humanitarian reason is constituting new, evolving publics with political effects. 


\section{Chapter Two}

\section{A Gathering Force: Publicity and Publics in Contemporary Humanitarianism}

Introduction

What do Bill Gates, Jackie Chan, Desmund Tutu, and a nameless California surfer with a curled moustache have in common? All four believe we are the distance between a thumb and a forefinger from "ending polio," and all that is needed "is you." 9 Their words are spliced with clips of multicultural faces in a video produced by Rotary International and embedded in the Global Citizen application. Sharing the video and signing the Rotary petition to "end polio" earns a Global Citizen two points towards the 'Polio Eradication' badge.

The video tells us we are needed. It does not address anyone by name, but Bill Gates and Jackie Chan point to the camera, point at whoever is watching the video, and say that it is 'you' who is needed. 'You' could be everybody and anybody. But why should you listen? By 'hailing' You, the viewer, the video is an act of interpellation, according to Louis Althusser (1970), where humanitarian subjectivity is constituted in the recognition of address and the identification of oneself with the You to whom the video speaks. Engaging with the moral

\footnotetext{
9 'We are This Close to the end of polio', Rotary International/Global Citizen, available at: <http://www.globalcitizen.org/Content/Content.aspx?id=b2ed2632-572d-495b-83674154104312c9> accessed 29 January 2013>.
} 
imperative in the recognition of address, Judith Butler argues that the vulnerable 'face' of the other, because it "comes to me from the outside," has the possibility to call one "out of narcissism towards something finally more important" (Butler $2004,134)$. But there is more at work in the appeals of this video than a process of hailing and recognition, or the ability of the face of the precarious other to generate a moral connection and obligation.

In the narrator's words, we are "this close to making sure that no child suffers a crippling disease ever again." So while the video shows the faces, the essences, and the needs of others, it appeals to a vision of shared human progress or flourishing, symbolized in the video by a young boy running through city streets, reaching serene wilderness. For this to be achieved, You are needed. You are the last thing that is required to end polio, and if You help and support Rotary International in their campaign to end polio, You become "a part of history" in your good action. The video addresses an amorphous You, constituting a public of You's in the collective subjectivity of the video's address.

By telling us there is a truth to scientific and medical progress, a duty of all to get involved, and a virtue in taking action, the video illustrates the complexity of logics in humanitarian appeals as actions of publicity aimed at the 'self. Indeed, contemporary humanitarianism is defined by the very problem of publicity, in its need for publics to rise up and rally against the self-interest of everyday life, the market and the sovereign state. Humanitarian appeals are public in their call for You, as an amorphous public, to be concerned for, 
advocate for and meet the publicized needs of often distant others in dire circumstances.

The transnational appeal of this publicity contradicts the classic, national conception of the public sphere and its connection between public and sovereign (Fraser 2007), but a language of publics remains useful because the explicitly political functions and implications of humanitarian appeals point to the leeching of public engagement across political communities in the calls for redress directed at a globally nebulous web of responsibility. Depending on the campaign, this nebulous sovereign can be composed of a multiplicity of state governments, the institutions and modalities of capitalism, intragovernmental organizations charged with the mutual administration of our world, the shadowy power of multinational corporations, the totality of those benefiting from and sustaining global inequalities ('the West'), or the totality of those 'selves' not subject to the circumstances causing suffering elsewhere ('You'). With government as the "domain of strategies, techniques and procedures through which different forces seek to render programmes operable" (Rose and Miller 1992), it is thus pertinent to ask how humanitarian appeals structure the problem space of global social justice by bringing suffering into the light of the public and calling for redress in particular ways. How do humanitarian appeals render the care for others operable through the transnational publics they gather? In short, what is at stake in the design of humanitarian publics for popular appeal? 
This chapter asks how humanitarian reason, as "the deployment of moral sentiments in contemporary politics" (Fassin 2011), governs those who advocate, work for, or support organizations and initiatives aimed at aiding others, with particular attention paid to popular appeals. Answering this question requires a methodological and theoretical approach that recognizes the connection of 'self with 'other' in humanitarian discourse and takes into account the multiplicity of logics bound up in humanitarian appeals. As the first chapter argued, humanitarian appeals are composed of historically contingent words, images, texts, sounds and ideas that are necessarily made public in their address to the 'self. Therefore, in order to work through the political implications of the call to humanitarian subjectivity, it is pertinent to ask what is public about humanitarianism, and what is at stake in this publicity.

This chapter argues that thinking about humanitarian campaigns and discourse as constituting publics enables a more complex understanding of the governing and motivating logics of humanitarianism than language that separates aid workers from citizens from consumers from spectators from activists. By looking at humanitarianism as constituting publics, it becomes easier to pick apart the political effects of both the logics and the designs of appeals vying for attention. The logics of humanitarian appeals are the focus for this chapter. They include a call to virtue, to duty, and to truth in the public revealing of human needs and in the demands this process of revealing place on those who pay attention. Humanitarianism is the discursive process of revealing and making public the condition and needs of others, and this exposure carries 
demands for action and attention. In this respect, the publicity of humanitarian reason works to create and foster transnational humanitarian publics by virtue of making the 'private' struggles of others public, moral issues for a globalized constituency.

Humanitarian publics are constructed by different logics and designs in the revealing of human needs and conditions, and the demands this revealing carries. To organize our understanding of humanitarian publics I venture to posit that in the multiple configurations and processes of address in humanitarianism, there are two main kinds of humanitarian public. These are professional humanitarian publics, which combine problems of humanitarian truth with problems and appeals to duty in the techne, or craft, of humanitarian action as vocation; and popular humanitarian publics, convened by truth and duty, but equally concerned with actions responding to the public needs of others as constitutive of modern virtue. The two blur and overlap, but it is with the second kind, popular humanitarian publics, that this chapter is concerned; for it is here that humanitarianism enters popular culture and our political imaginaries.

This chapter is organized into three sections. The first defines and discusses the terms 'public' and 'publicity' by charting the intellectual genealogy of the public, but with emphasis on Michael Warner and Clive Barnett's arguments premised on mediums of publicity, circulatory address and 'parasitical' public space. The second section uses this approach to publicness to 
consider what is public about humanitarianism, and why publics are relevant to humanitarianism. The third section breaks down the logics around which transnational humanitarian publics are convened across bounded polities. This section posits that the rationalities of truth, duty and virtue are assembled and continuously reconfigured in the creation of popular humanitarian publics, challenging public engagement as set within the boundaries of particular political communities or civic infrastructures. This sets the stage for the third chapter's analysis of how these three logics are mobilized through design to extend citizenship and the concept of political community to include all of humanity in the appeal to global citizenship. For, technological transformations alone are not responsible for shaping the ways in which the personal struggles of others are made public currency, because the eyes of the public are crossing national boundaries and peering through new and old lenses of capital, knowledge and modern virtue.

Who is Public? What is Public?

Public space. Public affairs. Public opinion. Public speaking. The language of 'public' in everyday use suggests that what is public is open, a shared space. Hannah Arendt first describes 'public' as an adjective meaning where "everything that appears in public can be seen and heard by everybody and has the widest possible publicity" (Arendt 1958, p. 50). She often uses the metaphor of lightness/darkness to illustrate the exposure that publicity bears upon things that are brought under the public gaze from the hidden household of the private 
realm. ${ }^{10}$ While such a stark distinction between a 'hidden' private realm of personal necessity and an 'open' public sphere of deliberation and politics ignores what is political about what is meant to be private, her description of the process of publicity as one of 'stepping into the light' illuminates the movement of public revealing, and the power in deliberation and scrutiny that weigh on things which are publicly exposed. This is a conception of 'public' that is traced by Arendt from the Aristotelian relation of citizen to city-state in Ancient Greece, where participation in the public realm of the polis defined man and signified the 'good life', in contrast to the private, bare life of subsistence and survival characteristic of animals (1958). The phrases 'public opinion' and 'public affairs' also lean towards this definition of 'public' as something that belongs to the 'general population' as a mass of political subjects with the potential to influence political outcomes.

The capacity of the public to act as the source and end of politics is challenged by Jürgen Habermas (1962), who argues that the modern liberal public sphere can be traced to capitalist social relations that opened up space for social criticism and cultural production for the fledgling bourgeoisie in Europe. What marked the publicness of the public sphere for Habermas was not an idealized and localized space of political participation akin to Aristotle's polis, but the broad circulation of texts - newspapers, pamphlets and novels - and the acts of discussion, self-reflection and cultural criticism within a public of readers separate from the state. Habermas, however, leaves us with the premonition of a

${ }^{10}$ For example, see her contrast of the darkness of the human heart with the light of the public in On Revolution, p.91. 
public sphere sullied by the manipulation of the market and emptied of critical thrust, characterized by the ubiquity of polls and graphs that measure 'public opinion'. The liberal public sphere may have a dull critical edge, but humanitarian appeals and actions are not reducible to a measurement of public opinion; they demand attention, concern, and action amongst a public that is not co-terminus with a political community.

To address what she sees as a contemporary upsurge in public interactions that cross national borders, Nancy Fraser (2007) throws a host of questions into the air regarding the efficacy and legitimacy of public opinion in a transnational world. She argues that the normative democratic bent of public sphere theory has privileged national politics as the site in which publics come into being. This poses problems for theories of transnational public organization that do not consist of a clearly defined polity addressing its sovereign. The central problem for Fraser is the ability of a transnational public sphere to uphold its democratic utility, prompting her to ask, among other things, if transnational public spheres could "conceivably generate legitimate public opinion, in the strong sense of considered understandings of the general interest, filtered through fair and inclusive argumentation, open to everyone potentially affected" (Fraser 2007.). While she conditions this ideal with a nod to the historical and contemporary democratic limits and exclusions of the Westphalian public sphere, Fraser is advocating for an instrumental conception of the public grounded in ideals of democratic legitimacy and efficacy. Yet, Fraser does not speak of how this thing called transnational 'public opinion' 
comes to act; implicit in her argument is an understanding that public opinion is inscribed with a demand for action or redress. In humanitarian appeals, the publicity of a totality of opinion or general will is not what defines public engagement, nor the call to action, nor the demand for redress.

In theorizing this relationship between political issues and individuals, Walter Lippmann describes the public as a 'phantom', an abstraction, summoned as judge for the "hardest problems," "which institutions cannot handle"

(Lippmann 1927, p. 121). The phantom-like qualities of publicness were brought to life with an art installation designed by Michel Jaffernou and Thierry Coduys, described by Bruno Latour as "an invisible work of art":

By moving through the various exhibits, the visitors will trigger various captors that will be used as so many inputs to trigger outputs which will give a vague and uneasy feeling that 'something happens' of which the bystanders are responsible but in a way that is not directly traceable. Politics will pass through you as a rather mysterious flow, just like a phantom.

Latour, 2005, p. 28.

But politics is not always a mysterious flow; often it is very deliberate. The participant in a demonstration or the writer of a letter to a newspaper editor have deliberate, and often traceable, effects. If we can extend Lippmann's metaphor outside of national politics, making the transnational 'public sphere' a phantom, reducible to opinion polls and visible in "that virtual, somewhat mysterious thing called "pressure"' (Marres 2005, p. 216), how can we understand the purposeful gathering or networked connection of transnational individuals in the recognition of a shared concern? 
The public sphere must be defined in separation from its publics. Theorist and literary critic Michael Warner posits that instead of only being members of a national body politic, public sphere, or 'public', "the publics among which we steer, or surf, are potentially infinite in number" (Warner 2004, p. 9). He defines 'publics' in three ways, first as a kind of mass or population, second as "a concrete audience," and third as "the kind of public that comes into being only in relation to texts and their circulation - like the public of this essay" (p. 413). Central to his argument is this third definition, a public that "enables a reflexivity in the circulation of texts among strangers who become, by virtue of their reflexively circulating discourse, a social entity" (p. 12). This public is infinite and fluid in size, for it is not defined by the presence of countable members but the reach, dispersal, and recognition of address between strangers. Clarifying Warner, Clive Barnett argues that although "publics are assembled" "through various combinations of devices, procedures, things and mediums" of publicity, what constitutes publics is not the "act of address" on its own, "but the relation of attention that is established in the space that separates and joins" the act of address and the act of response (Barnett 2008, p. 14).

What Warner's conception of publics provides is a framework for taking into account the transnationality and power of address without diminishing the role of self-recognition and self-motivated attention in identifying oneself as part of a public, whether one is a concerned citizen or a cultural critic. Yet, Warner's public is primarily a 'social entity'. Outside of his theory of 'counterpublics', he leaves little room for publics to constitute themselves as political entities, or 
more critically, as entities imbued with mechanisms of governance through the modes and content of their address. By this, I mean that is worth considering that publics, as both political and social entities, are often addressed and convened not simply around an act, an issue or a text, like this essay, but also around calls to act. To fill this gap, Clive Barnett clarifies a more explicitly political interpretation of Warner's publics by emphasizing that public discourse depends in part on perlocutionary acts, "acts which aim to persuade or convince, warn, or alarm other people," (2008, p. 22). They are acts that work as claims for attention (p. 22), while restricting alternative articulations. For example, the narrative of the polio video may encourage You to sign a petition or support a cause, but it has the perlocutionary effect of rendering polio as a shared, popular responsibility, solvable through philanthropic aid. Consequently, a public may organize itself (Warner 2004), but for Barnett, publicness and public action is dependent upon communicative and socio-cultural infrastructures, like the threads of philanthropy that cast health issues as public concerns. Barnett argued that this relationship between publicness and its conditions of possibility give public space a 'parasitical' quality, but public address and response does not simply leech from current and historical structures (as a parasite does a host) without circulating back and reinforcing those very structures (like the video does for certain threads of philanthropy). So in the function, form, and history of address there is room for government in the shaping of ideas, behaviors, beliefs and actions in the constitution of publics, but the logics and designs that work to grab and sustain the attention of publics also carry effects for the communicative 
and socio-cultural structures that give publics their conditional existence. It is this circulatory relationship that illuminates how public appeals can operate as techniques of governance not only upon those they address, but also upon the environments, ideas, and mediums of communication that enable phenomena to emerge into the light of public concern.

\section{A Humanitarian Public?}

There may not appear to be much insight in claiming that humanitarian discourse constitutes publics, given their amorphous, and somewhat intangible qualities. But the blurred spatialities of humanitarianism, the publicity required for its appeals, and the multiplicity of rationales and logics bound up in humanitarian discourse hint that a language of 'publics' may be better suited to describe the gathering forces of humanitarian knowledge and collective subjectivity than a lexicon dependent on more bounded signifiers like 'social movement' and 'interest group'. Humanitarian discourse does not purport to represent a group, nor does it necessarily speak from an occupied public space through demonstration. Rather, humanitarian appeals are capable of articulation both in the street, and in the 'virtualized' public spaces of television and the Internet (Barnett 2008, p. 8). So like publicness itself, humanitarianism "resides nowhere else than in the treacherous and promising space that is enacted by throwing words, signs, and tokens out into the world" (Barnett 2008, p. 9).

The subjectivities of humanitarian discourse and humanitarian address both affirm and challenge the defining characteristics of publics that Micheal 
Warner describes in his book Publics and Counterpublics. As illustrated by the polio video, "the address of speech is both personal and impersonal" (2004, p. 415), describing the broad self-recognition and performativity in humanitarian address. Humanitarian publics are also relations "among strangers" (p. 415), but they challenge Warner's insistence on self-organization. This is because those of us who find ourselves paying attention to the kind of humanitarian address featured in the polio video may constitute a humanitarian public, but there are mechanisms of government in the video's address, and a full, operationalizing interface in the Global Citizen application that is not fully acknowledged in Warner's circulatory, self-organized conception of publics. Warner argues that a public "must first of all have some way of organizing itself as a body... it must be organized by something other than the state" (p. 415) but his examples of literary criticism and queer counterpublics imply that the self-organization of a public is an organic process, rather than something often imbued with asymmetrical and problematic power relations in defining and shaping the concerns and texts that grab public attention.

Lastly, although humanitarian publics may be constituted through texts, objects and procedures as per Warner's circulatory and spatially amorphous definition of a public, humanitarianism does have an arranged spatiality between those who humanitarian actions aim to help, and those who advocate and act on their behalf. This distance destabilizes the legitimacy of humanitarian publics as "poetic world making," for "all discourse or performance addressed to a public must characterize the world in which it attempts to circulate, and it 
must attempt to realize that world through address" (p. 422). The video calling for an end to polio does not specify where polio remains a threat, but the contrast between the celebrities, leisurely surfer, and the running African boys imply a similar distance between viewer and vaccine recipient. This distance is bridged by the construction of a shared moral world in which the potential of these boys depends on You. Lilie Chouliaraki posits that the multimedia efforts to build a shared moral world and the tensions inherent in this have been "intensified" by the "mass media" "because they constantly confront us with realities that occur too far away from everyday life for us to feel that we can make a difference to them" (Chouliaraki 2001, p. 2). But it is not so much physical distance that defines the spatiality of humanitarian appeals, rather a particular arrangement in the appeals that strictly demarcates those in need from those who should feel an obligation or an ability to assist. It is an inherent tension in humanitarian publicity that is produced by the reflexive world making of publics, a process that strains to foster attention and engagement from some, in the revealing of the suffering and needs of distinct others. This tension prompts the question of whether the publicness that gives humanitarianism its moral weight and condition of possibility paradoxically threatens the moral thrust of humanitarian discourse - the need to recognize others as humans.

The 'massification' of the other through the anonymous faces, emotions and the performance of needs through multimedia could be argued to be an extension of an Arendtian 'politics of pity', whereby the relation between self and other in need is reduced to an asymmetrical sympathy that cannot possibly 
be experienced on a personal level because of the distance involved (Boltanski 1999, p. 13). Arendt charges that when political interactions are grounded in compassion, compassion "abolishes the distance, the in-between which always exists in human intercourse... stating in complete and even naïve sincerity that it is easier to suffer than to see others suffer" (Arendt 1963, p. 81). Arendt's skepticism of compassion derives from her delineation of the public sphere, for Arendt herself may have found a peculiar contradiction between the perceived goodness of humanitarianism and the common publicity of its discourse. She understood the Christian tradition of goodness as capable of losing "its specific character of goodness, of being done for nothing but goodness' sake," "the moment a good work becomes known and public" (Arendt 1958, p. 74). Likewise, she argued that once sentimental motives for action are "brought out and exposed for public inspection," they become objects "of suspicion rather than insight," because "the motives behind [good] deeds and words are destroyed in their essence through appearance; when they appear they become 'mere appearances' behind which again other, ulterior motives may lurk, such as hypocrisy and deceit" (Arendt 1963, p. 91). What she did not elaborate on was whether goodness could enter the public realm for goodness' sake, in order to multiply the effect of good work. With humanitarianism, goodness has entered the public realm, but whether or not it has kept its inherent goodness is up for debate.

Arendt not only separates publicness from goodness, but also from pain, which "is so subjective and removed from the world of things and men that it 
cannot assume an appearance" in the public realm at all (Arendt 1958, p. 51). The appearance of suffering and the visualizations and narratives of pain in humanitarian discourse may not equate with the literal sharing of one's pain with another, but as World Vision could attest, the publicity and broadcast of suffering through mediated narratives calls for attention and action. The attention that is garnered by revealing pain and suffering in the public realm suggests that it may be precisely the distance between pain and "the world of things and men" that give pain and suffering in contemporary politics such credence and currency - it is the very thing that catches the public eye, it is the process by which a humanitarian crisis, situation or struggle is made public. Michael Barnett theorizes that this is in part due to humanitarianism's role as a panacea to the reality of human mortality, in that it "helps the living come to terms with their ghosts. It is a form of theodicy, providing a means by which survivors can reconcile their belief in the possibility of a more perfect world with cruelty, suffering and evil" (Barnett 2011, p. 226). So although there may be strain in the inherent publicity of humanitarian appeals and discourse, humanitarian sentiment is public in contemporary politics. It is no longer fruitful to discount ethical imperatives in international politics as hypocrisy or empty window dressing to the self-interested realism of the international order. Instead, we should look to the assumptions, logics and appeals of ethical discourses like humanitarianism to uncover the subtler, but just as real, ways in which we are governed through its publics. 
The centrifuge of humanitarianism is in tension with its own publicity, through the spatiality inherent in its appeals to aid distinct others, and the strain between the broadcasting of goodness, the pursuit of justice, and the limits of the self. Thinking about humanitarian discourse as constituting publics, however, allows for a more nuanced analysis of the range of logics mobilized in humanitarian reason while taking into account the role of the 'self' in the recognition of address and the constitution of collective humanitarian subjectivity. So while my understanding of humanitarian publics is generally consistent with Warner's theoretical framework, humanitarian publics also have the potential to illuminate the shaky boundaries between public, audience, spectator, citizen and activist, to get at the heart of political engagement in our interconnected and networked world. Yet, humanitarianism's moral premise that all people share an essential human essence and deserve to be aided if their lives are threatened cannot explain how publics are formed across political boundaries. Humanitarian reason is made public in particular ways, through the design of address and response, and through the articulation of supporting logics. What logics, what discourses work to take hold of the imagination of a transnational humanitarian public? The next section will address this question by considering the public implications of a few logics of humanitarian reason, before the third chapter dissects their articulation in a particular technological design. 
Epistemic Claims and the Search for Humanitarian Truth

In its call for You to sign a petition for the resources needed to eradicate polio, the Rotary video appeals to a vision of the world in which human progress is possible and perfectible through scientific advancements. These advances are measurable - remember that we are the distance between a thumb and a forefinger from eradicating the disease - and necessarily good. Although medical and scientific advancements have greatly contributed to quality and length of life around the globe, the focus on the perfectability of knowledge, whether in the health sciences or in information systems for humanitarian response, sidelines the political by encouraging empirical truth. The persuasive appeal of truth discourses in humanitarianism is related to the advent of developmentalism, as chronicled in the previous chapter, because epistemic claims in humanitarian discourse are biopolitical, in that they take human lives as their object of truth and situate a population as "the final end of government" in the unlimited quest "to improve the condition of the population, to increase its wealth, its longevity, its health" (Foucault 1998, p. 105). This holds transnational resonance, for humanitarianism is "offered as a possible response" to the various threats that are "seen as increasingly impinging human possibility" (Feldman \& Ticktin 2010, p. 24). But it is not the moral claim of humanitarianism alone that drives the government of populations and the pursuit of human progress. Truth in progress, empirical claims, and technological advancement all give shape to the articulation of humanitarian reason, demanding attention from humanitarian publics with both political and anti-political effects. 
As Andrew Barry $(2001 ; 2002)$ argues, there are anti-political effects to information production and epistemic claims, for they reduce the problem space of politics, within which things and ideas become contestable. Information alone creates this effect, for information "demands a practical and technical intervention in the world which necessarily abstracts an object from the complexity of its environment" (Barry 2001, p. 155.). While Barry (2001) looks at how the chemistry of air becomes political through the production of information, similar anti-political effects are visible within the centrifuge of humanitarian discourse. In the context of the polio video, the implicit epistemic claim that polio eradication would free children from the shackles of disease overshadows the possibility of contesting the degree to which funneling economic, political and social resources into one disease is an adequate response to the needs of those living in areas where a lack of general health care, nutrition and sanitation contribute to the production of other afflictions and forms of suffering. General health is not as easily measured and calculated as a population infected by a virus, which shows how the pursuit of empirical knowledge serves "to create new objects of scientific investigation while marginalizing other lines of inquiry which do not feed directly into the process of information production" (Barry 2001, p. 154).

Information and epistemic claims have another effect: they demand attention. For Lippmann, this was a defining problem of public action, for "if by some development of the radio every man could see and hear all that was happening everywhere, if publicity, in other words, became absolute" 
(Lippmann 1927, p. 44), how much time would we spend paying attention? Lippmann argues that we would probably, "in desperation, throw off the switch and seek peace in ignorance" (p. 44). The frustration of information is in its demand for attention and, often, action. Barry clarifies this demand, in that "the very idea of information implies a relation between a set of natural or social entities which are objects of knowledge and a set of actors who are or should be informed and knowledgeable" (Barry 2001). He argues (2002) that the quest for empirical knowledge and its demands create 'metrological regimes', whereby a "political debate" is translated into the "economic field," "in which the measurement of properties becomes increasingly important" (p. 89). As the video tells us, we are, after all, the distance between a thumb and a forefinger from eradicating polio. The production of an 'economic field' is most visible in the exercise of graphing, mapping and the construction of information systems, which aim to make information visible, workable and digestible.

Reliefweb, the "specialized digital service" of the United Nations Office for the Coordination of Humanitarian Affairs, ${ }^{11}$ is dedicated to this kind of work: it renders humanitarian 'conflicts', 'crises' and 'disasters' knowable through statistics, graphs and mapping technology. The service is in the beta phase of launching interactive world maps that use different sizes of red dots to denote where "an ongoing crisis or disaster" is taking place and its scale. ${ }^{12}$ The website also consolidates information into 'humanitarian dashboards', with statistics,

\footnotetext{
11 'Reliefweb', < http://reliefweb.int/> accessed 5 March 2013>.

12 'Mapping Conflict in the DRC', Reliefweb, < http://rwmaps.github.com/rw-drc/\#-

13.943503820958155,36.32617187499999,7\&layers=lra,sec,idp> accessed March 5 2013>
} 
icons, maps and reports for each country. A similar movement is visible in the layout of the Global Citizen application where the polio video is hosted under the category 'Polio' and represented by the symbol of a red blood droplet. In this way, polio is presented as one of many delineated 'global issues' that are described and mapped out by the application with coordinating, representative logos. These metrological regimes create 'humanitarian information' and imply that when properly informed, humanitarian action can take on an apolitical, epistemic resonance. Thus, according to an aid worker at a 2011 TEDx conference in Geneva, the elusive ideals of humanitarianism can be met because 'we now have the tools, we now have the possibilities."13

He was speaking at a TED talks offshoot, titled TEDxRC2, which was planned as a "worldwide event to multiply the power of humanity and start a global conversation about tomorrow's humanitarian challenges and opportunities." 14 It was an event that turned humanitarian discourse in towards itself, so while this speaker used the truth discourses of communication technology to argue that "we need to bring the humanitarian world from analog to digital," he was speaking about a different We than the polio video; he was speaking of a We of humanitarian professionals.

13 'Shifting Aid from Analog to Digital', available at: http://www.youtube.com/watch? $v=I d 3 X V K 4 n K C U$ accessed 25 January 2012> 14 'Storify', TEDxRC2, available at : <http://www.tedxrc2.com/page23/> accessed 25 January 2012> 
Humanitarian Duty and Popular Professionalism

David Rieff's bestseller, A Bed for the Night: Humanitarianism in Crisis (2003), was written for a popular audience but from his perspective as a journalist with experience in documenting and writing polemics on humanitarianism and aid work. The book was a call to humanitarians - as aid workers, journalists and intergovernmental officials, but also as regular citizens - to analyze "this peculiar amalgam of voyeurism and witness that we all practice," and return to the root of humanitarian duty from the roll it now plays as "a catchall for the thwarted aspirations of our age" (Rieff 2003, p. 335). He characterizes humanitarianism foremost as "the vocation of helping people when they most desperately need help, when they have lost or stand at risk of losing everything they have, including their lives" (p. 27). Rieff charges that the ability of the humanitarian to save lives has been compromised by the politicization of humanitarian organizations and aims through the alignment of humanitarianism with state interests, liberal developmentalism and military interventions. What is at the heart of Rieff s critique is the question of duty: what kind of duty do we have to others, and what are its limits? Duty is central to the moral imperative of humanitarian action, aid and attention, but duty is mobilized and justified in many different ways.

There is duty embedded in the demands of ongoing progress in knowledge, and in the demands of information and epistemic claims. But for Rieff, humanitarianism is a vocation, and problems of duty in this respect are primarily addressed to the practitioners of humanitarianism and its publicity, 
such as aid workers, journalists, politicians and inter-governmental professionals. Yet, as a bestselling book, Rieff is also implicitly addressing a popular public, with the moral thrust of the professional responsibilities of humanitarian duty bleeding into popular conscience as a result. Because professionals are experts and "specialists who manage things" as a 'psuedoscience' (Dewey), this popular professionalization of humanitarianism emphasizes the pursuit of a techne, or craft, of humanitarianism. The bureaucratization and professionalization of humanitarian techne creates the illusion of rule by administration, or rule by nobody (Arendt 1958, p. 45), where organizations without faces tell us what a humanitarian crisis is, and how to find it on a map. But John Dewey argues there are limits to expert rule, in that "expertness is most readily attained in specialized technical matters, matters of administration and execution which postulate that general policies are already satisfactorily framed" (Dewey, 206). Rieff's argument illustrates that this is something that humanitarianism as a vocation or act has not achieved. Indeed, despite the veneer of precision afforded metrological regimes like those created by Reliefweb and Global Citizen, humanitarianism is "a site of ambivalence and undecideability" (Walters 2011, p. 144). So while the administration of humanitarian reason may bleed into popular conscience, humanitarian initiatives, programs and campaigns continue to appeal to the public for their involvement and support, and for the consultation and contestation of humanitarian aims. 
As the popularity of David Rieff's book illustrates, claims to truth and duty through humanitarian reason do not just demand attention of the professionals tasked with specializing in humanitarian problems, but also of the citizen, the consumer, the book reader, and the news watcher. The "regulatory effects" produced by the demand of information come out of the implication that once informed, one is transformed in some way (Barry 2001, p. 153). Humanitarianism is on its own a duty - an obligation to recognize and respond to the publicized needs of others - so humanitarian information is all the more demanding of its publics. This is because suffering or necessity is brought into the light of the public, demanding attention in its spectacle, in its challenge to our mortality. Yet, Walter Lippmann tells us that the assumption that "if only he could be taught more facts, if only he would take more interest, if only he would read more and better newspapers... he would gradually be trained to direct public affairs," is "a false conception of the way the public acts" (Lippmann 1927, p. 145). The relative lack of attention to the almost four million deaths in the Democratic Republic of the Congo at the time of the sensationally tragic South Asian tsunami in 2004 (Forsythe 2009, p. 59) illustrates Lippmann's point: public engagement and attention is fickle and not directly associated with access to information. How then, can we account for the appeal of the polio video and its operationalizing structure, the Global Citizen application? If the truth claims and moral obligation of humanitarianism are not enough to explain the transnational gathering of concerned people into these entities called 
humanitarian publics, what is missing to account for the power of humanitarian reason?

Popular Publics: Humanitarian Virtue for the Masses

The narrator of the polio video may tell You that we are close to eradication of the disease, and You should feel obligated to do your part, but humanitarian appeals also tell us that paying attention and taking action are virtuous activities. For Aristotle, such virtuous activities are eupraxia, or good things, through which we can strive for eudaimonia, or personal happiness and flourishing (Sherman 1997, p. 12). Philosopher Nancy Sherman defines virtues as "character states that dispose us to respond well to the conditions of human life through both wisely chosen actions and appropriate emotions" (p. 5). These character states are essential for Aristotle, who saw that "the best human life will require at its center the exercise of virtue, or excellent human (social) functioning" (p. 5). The exercise of virtue is actively called for in modern humanitarian discourse that is translated for popular appeal. The polio video is one such example of humanitarianism for popular audiences, and its soundtrack, cinematography and narration suggest appropriate emotions (sympathy, resolve, hope) and actions (consider, respond) for the viewer, constructing the virtuous 'character state' of 'humanitarian' in its address.

This small but powerful form of government also draws on the Christian roots of humanitarian appeals by governing "in the practice of spiritual direction, the direction of souls" (Foucault 1998, p. 123). In his final years, 
Michel Foucault became preoccupied with this "art of living" that was not so much concerned with the collection of virtues but "attributes of being" or "modalities of experience" (Paras 2006, p. 128). To Foucault, the ancient Greek virtues and "techniques of life" were not strict moral codes, but answered the question as to "how to govern one's own life so as to give it the most beautiful form possible - be it in the eyes of others, of posterity, or of oneself" (p. 128). Although Foucault was more concerned with an art of living through truth in quasi-spiritual self-interrogation and aggregate 'modalities of experience' such as "tranquility, beatitude and happiness" (p. 128), the moral grounds for this pursuit speak to how being a humanitarian, acting like a humanitarian, and engaging publicly take on resonance beyond mortal self-interest, and beyond Nancy Fraser's description of a politically instrumental public sphere. Indeed, humanitarianism can be seen as a path to personal legacy and spiritual fulfillment, as sung by Beyoncé in the music video discussed in the previous chapter. Consequently, humanitarian appeals and humanitarian engagement do not just call to us to recognize and rectify what should be, or how we should act, but, powerfully, who we should be.

When addressed to a popular audience, this virtuous appeal serves as a mobilizing logic in the texts, images, videos and devices that grab popular attention and instigate engagement, creating popular humanitarian publics that cross and blur political communities. Virtuous perlocutionary effects are most visible as techniques of government in public campaigns with wide reach, for they aim to mobilize mass publics for collective impact. To understand the 
political effects of popular humanitarian publics requires focusing on the specifics of popular humanitarian campaigns, because it is in the texts, images, videos, devices and mediums through which virtue is articulated that virtuous, epistemic and moral claims become visible. The following chapter looks at what is at stake in the popular humanitarian public assembled by the Global Citizen application and festival, in order to examine the multiplicity of logics and threads of reasoning, from consumption and capital to social communication and cosmopolitan citizenship, that are being reconfigured to powerful effect in the popular, networked, transnational publics of humanitarianism.

Conclusion: Logics and their Effect

This chapter has argued that a language of publics is well suited for uncovering and understanding the logics that call individuals towards collective but amorphous humanitarian engagement across political boundaries. For, being public means being seen and being heard by 'everybody', and humanitarianism is defined by the very act of making the suffering or needs of others public, of revealing these things in the gaze of the public eye. It is not simply a natural altruistic impulse or this act of revealing that binds humanitarian publics to a shared cause or concern, but rather logics such as truth, duty and virtue that are mobilized in the articulation and display of suffering, and in the proposed redress. These logics carry political and anti-political effects, evidenced in how biopolitical truth discourses, 'humanitarian information', and the professionalization of humanitarian techne, or craft, work to reduce the field of 
contestation in humanitarianism through the pursuit of knowledge claims. Yet, humanitarian reason is not powerful in contemporary politics by the thrust of its moral obligation or truth claims alone. The virtuous appeals of popular humanitarian campaigns carry the quest for personal legacy, human flourishing and spiritual fulfillment in their wake. These virtuous appeals present humanitarianism as a powerful doctrine of self-realization, grabbing at the conscience of popular imaginary and replacing the democratic instrumentalism of Nancy Fraser's publics with self-fulfillment.

It is in the more visible, popular aspects of humanitarianism that its motivating, political rationalities are "constantly undergoing modification" (Rose 2006), with consequences for how we think of social justice and our capacity to act politically. The next chapter will look at what is at stake when these modifications include a humanitarianism that is articulated through technology and design to become part of popular culture and inseparable from patterns of consumption, from the demands of the market, from social communication and from networked life. It is a reconfiguration of humanitarianism that is pushing and pulling at the limits of citizenship and political community. 


\section{Chapter Three}

Give me an iPhone and I Will Raise the World: Designing Popular Humanitarian Publics, Encouraging Global

Citizens

Introduction

"WE ARE GLOBAL CITIZENS," proclaims the homepage of Global Citizen in a graphic slide next to an image of Somali-Canadian hip-hop artist K'Naan holding a drumstick to the heavens. ${ }^{15}$ "We take action to fight extreme poverty. We create change for a better world." Another slide appears, this time a photograph of a crowd of young people holding their hands in the air in the shape of a circle, along with the text, "Support causes you care about, earn points and redeem for rewards." The next slide features the outstretched arm of a young African child, pointed in a cutting motion to illustrate that "Extreme poverty has been halved in the last 30 years. Global Citizen is your tool to create change." The final slide sums up the entirety of this bizarre amalgamation of popular culture, humanitarian sentiment, virtuous subjectivity and consumption, with "LEARN. ACT. EARN. ROCK." sketched over a sepia image of a rockstar crooning to a massive audience in New York's Central Park. The

15 Sliding graphics on homepage, 'Global Citizen', <http://www.globalcitizen.org/> accessed 5 March 2013> 
photograph is taken from the stage, looking out over the crowd, giving the viewer the feeling that they, too, are playing for an audience.

Music as a form of political protest is nothing new, and neither is its use to inject popular appeal into the fight against social injustices. From Woodstock to Live Aid to star-studded charity telethons, music has been part of discourses that bring people together for certain aims. So when representatives from nongovernmental organizations and philanthropic foundations graced the stage from the photograph with the likes of The Black Keys and Neil Young on the Great Lawn of Central Park on September 29th, 2012, the event appeared to be just the newest incarnation of popular humanitarian publics that perform politics and humanitarian optimism through popular culture.

Yet, what was dubbed the 'Global Citizen Festival' by its organizers, the Global Poverty Project, ${ }^{16}$ deserves reflection beyond a frivolous or dismissive critique of the sincerity and efficacy of popular culture as a source of dissent and mobilization. What distinguishes the festival from its predecessors is not the number of viewers the festival drew through both television and streaming live video, but a model of mass participation for allocating tickets and structuring the event that frames the festival as the means to build a sustainable movement of 'Global Citizens' to end 'extreme poverty' worldwide. ${ }^{17}$ Tickets to the festival were only available to those who registered as 'Global Citizens' and earned

\footnotetext{
16 The Global Poverty Project is a transnational advocacy organization originating in Australia. More information available at their Australian website, <http://www.globalpovertyproject.com/> accessed 5 March 2013>.

17 The application is accessible through www.globalcitizen.org, and the festival page is www.globalfestival.com
} 
'activist points' on the online and mobile Global Citizen application. The festival was promised to be just the first of many rewards to come, with activist points earned by sharing videos and information provided by the application on Facebook and Twitter. The shareable content educates others as to the moral imperative of self-identifying as a Global Citizen, and as to what ending 'extreme poverty' would require in terms of improvements in 'public health', 'maternal health', 'food security', and other delineated 'global issues'. The appeals of these videos and texts are aimed at generating funds for partner NGOs and foundations through private and public contributions to end 'extreme poverty'. Thus, in the hopes of mobilizing a force for justice, the Global Citizen application blurs the boundaries between social movement and festival, between philanthropy and social justice, and between spectator, participant, and citizen.

With the various connected processes of globalization, including technological advancements in communication and transportation, the proliferation of interdependent networks of international trade, and increasingly complex networks of migration, "full public life is increasingly global in cause and consequence" (Hilde 2004, p. 120). Popular humanitarian campaigns urging us to recognize our interconnections and give back to distant others around the globe have proliferated, challenging nationally or locally bounded conceptions of civic action, civic virtue and public engagement, while national legal-juridical citizenship continues to be securitized and reinforced. It is within this paradoxical reconfiguration of public life that the Global Poverty 
Project's Global Citizen application and festival convene a transnational humanitarian public of the national citizens of wealthy nations.

This chapter focuses on the Global Citizen application and festival in an attempt to pick apart how popular humanitarian publics are not only articulated through the logics of truth, duty and virtue, but are "made with things" (DiSalvo 2009, p. 50). Responding to Bruno Latour, who had asked 'How are things made public?' (2005), Carl DiSalvo insists that the inverse has remained "unaddressed - but it is exactly this question that also should be asked as the products and processes of design are increasing [sic] politicized and used for political ends" (DiSalvo 2009, p. 50). The design of technology, texts, and interfaces such as the Global Citizen application is just one of the many 'conditions' which make practices "acceptable at a given moment" (Foucault, 75). The concept of global citizenship itself is interwoven into the "various combinations of devices, procedures, things and mediums" (Barnett 2008) that are put together by the Global Citizen application to assemble and tool a popular humanitarian public.

How citizenship is constructed and mobilized or how the citizen is formed and brought into being, is multivalent, depending on the sites, scales, acts and actors involved in any particular configuration of citizenship. So, according to Engin Isin, we must comprehend citizenship as a fluid, dynamic, "instituted subject-position" and ask not "what is citizenship?" but rather, "what is called citizenship?" (Isin 2009, p. 369). Keeping a perspective on the constitution of publics reminds us that asking 'what is called citizenship?' is not asking for an account of how and why individuals might recognize themselves as 
humanitarian global citizens, and act as such. For this end, we must also ask how citizenship is constructed or designed. This question is all the more pertinent when looking at new configurations of citizenship that do not ascribe a status to individuals but ask for the voluntary participation and self-recognition of individuals. For the Global Citizen application, this means looking at how the campaign and interface are designed to persuade the youth of wealthy countries to transcend traditional boundaries of political community through interactive and networked technologies and humanitarian reason.

In order to explore what is at stake in the appeals, logics, devices, designs and functions of this kind of humanitarian public, this chapter asks how humanitarianism and global citizenship are designed by the technologies and discursive practices of the Global Citizen application. What is at stake in the picture of the compassionate, global 'citizen' made possible by the application as an interface and as a tool of humanitarian reason? How are popular humanitarian publics being tooled and designed, and what effect do these designs have for social justice, political action, and the relationship between oneself and the needs of others?

To explore these questions, this chapter begins with a brief outline of the genealogical roots of global citizenship, and why, given scholarly criticisms of cosmopolitan citizenship, the language of citizenship is useful for analysis and not simply dismissible as an empty brand name for the application. There is also more at stake in the application than the use of technology - it is the design and implementation of technology that speak to both the ways in which the call to 
humanitarian subjectivity is shaped by the application, and the larger cultural and social milieu in which the application, as a technology, is embedded. Consequently, the chapter will analyze how the application, as a 'technological object' with a history, reconfigures multiple threads of humanitarianism through a technological tooling of global citizenship. But the Global Citizen application also cannot be considered outside of the market logics of contemporary political life, with the current "neoliberal moment" "witness to ever-sharpening delineations of the marketplace as constitutive of our political imaginaries" (Mukherjee \& Banet-Weiser 2012, p. 10).

This chapter argues that the application governs by designing and 'tooling' the popular humanitarian public it creates, in that the application provides possibility and shape for action. It does so with an online interface of global citizenship oriented towards a pedagogy of humanitarian virtue that is grounded in market rationality and liberal governmentality. This design of humanitarianism obscures more inclusive and democratically progressive visions of global citizenship, but leaves open the possibility for more critical engagement within the awakened public it creates. Although just one example of how popular humanitarian publics are shaped, designed and governed for particular ends, the Global Citizen application is indicative of larger trends of self-mediation and consumerism in the neoliberal moment, trends that are reconfiguring how we see ourselves as public actors in our electronic, networked 'cosmos'. 
Global Citizenship: A Humanitarian Interface

Citizenship, conventionally understood as membership in a bounded political community (Baubock \& Guiraudon, 2009), is premised upon the moral value of the common polity. Citizenship speaks to belonging in a community that is founded on a shared political culture, whether the connections between members are tangible or only imagined. Thus, citizenship is not limited to a legal-juridical status of membership constrained by borders, but is "a relation that governs the conduct of (subject) positions that constitute it" (Isin 2009, p. 371). This is particularly salient for conceptions of global citizenship where a lack of formal institutions and structures at the international level leave the 'global citizen' to emerge as a virtuous, humanitarian social identity amenable to governance rather than a legal status beholden of certain rights. But how can the appeals to form a popular humanitarian public of global citizens be understood? What is at stake in calls to citizenship that have no legal-juridical status to speak of, only the connection of humanitarian reason?

The interconnected processes of globalization have prompted a tension in citizenship between the "co-existentiality of state, nation and people" that defines Westphalian citizenship as it is practiced in our international system (Baubock \& Guiraudon 2009, p. 439). Evolving configurations of politics are shrinking or extending public interactions and the political community of citizenship to sites within, across and beyond national borders. The extreme example is the use of the language of citizenship to describe belonging to a 
political and moral community of all of humanity, expressed by the phrase 'global citizen'. This is not so much a "realignment of citizenship" (Baubock \& Guiraudon) but rather a reconfiguration, because the legal-juridical structure, institutional foundations and moral basis of national citizenship are not simply 'scaled up' or 'realigned' to fit a global political community. Instead, global citizenship challenges what is even meant by the term 'citizen'.

Despite the pronouncement that the recent era of globalization is producing world citizens (see Schattle 2008, and Nussbaum 1998, among others), global citizenship is not a new concept. Indeed, as pointed out by Hans Schattle, the roots of global citizenship predate the contemporary model of national citizenship as birthed in western thought by the French and American revolutions (Schattle 2008, p. 2). Chapter one outlined some of the genealogical traces of global citizenship from the proclamation of Diogenes the cynic, to the rational cosmopolitanism of Immanuel Kant, to the call for a liberal pedagogy of world citizenship by Martha Nussbaum. Throughout, world citizenship and cosmopolitanism have been mutually constituted to appeal to a higher moral order for human organization. Indeed, it is difficult to disagree with its humanitarian vision of the world that recognizes the common moral worth of all individuals, regardless of location and difference. Yet, the humanitarian arguments for global citizenship and cosmopolitanism remain controversial topics across academic disciplines, making it more difficult to take the appeals of the Global Citizen application seriously. 
Most criticisms are aimed at global citizenship's reliance on ethical, rather than legal qualities of citizenship, its assumed universality, and the trivialization of the privileges of national citizenship. Yet, an important root for discord over the term 'global citizenship' lies with the language itself, for, as Andrew Linklater points out, "on any strict definition of citizenship, the term is self-evidently and unalterably oxymoronic" (1998, p. 24). Critical citizenship studies theorists often focus on the construction of citizen as necessarily constituted by the citizen's other (see Macklin 2007), but who is the outsider that the global citizen is defined against?

There is also no global institution for granting world citizenship, despite the rise in power of inter-governmental organizations such as the World Trade Organization, the International Monetary Fund, and, of course, the United Nations. There may be a globally nebulous web of responsibility or authority, but detractors claim that the lack of institutional and legal governing structure means that there is no shared rule and legitimate authority to grant a tangible, concrete status or bundle of rights, obligations and practices on a global scale, nor could there ever be a shared global identity and culture upon which a political community could be founded (Dower 2000, p. 554). This leaves global citizenship to the privileged 'citizen pilgrim', to use Richard Falk's term (Furia, 2005).

The cynical picture of the global citizen as merely the privileged traveller, volunteer, humanitarian professional or transnational working elite may be a valid representation of many self-recognized global citizens, but there is still 
value in reconfiguring citizenship on a global scale. What critics of cosmopolitanism and global citizenship miss is the moral content of citizenship that forms the basis for the recognition and the "right to claim rights" (Isin 2009, p. 370) it affords to equal members of the greatest political community of allhumanity. Some scholars concerned with global issues speak of humanitarian obligations and rights (for example, see Onora O'Neill or Peter Singer), but do not use the language of citizenship to describe this relation (Dower, 2000). So why speak of citizenship at all?

Critical citizenship studies theorists such an Engin Isin show that citizenship as a tool and language of analysis is valuable beyond both T.H. Marshall's liberal idea of citizenship rights, and republican notions of citizenship tied to participation and belonging in a specific polity. Isin's conception of 'acts of citizenship' skirts between the binary of citizenship as either a status or a practice, by asserting that acts of citizenship transform publics, in that they "transform forms (orientations, strategies, technologies) and modes (citizens, strangers, outsiders and aliens) of being political by bringing into being new actors as activist citizens (claimants of rights and responsibilities) through creating new sites and scales of struggle" (Isin 2008, p. 39). Thus, citizenship is a 'relation' for Isin - one that can be enacted in publics outside, between, within, or in opposition to existing Westphalian citizenships and national borders.

It is in this sense that Nigel Dower (2000) counters academic criticisms of global citizenship by defining global citizenship as reflective of, but not synonymous with, a humanitarian ethic. For both Isin and Dower, there is 
something more in citizenship than an ethic of responsibility and awareness. That 'something more' is a subject-position, not instituted through legal recognition but established through public self-recognition and response to discursive address. It is in this sense that global citizenship itself becomes an interface for humanitarian sentiment, giving shape to humanitarianism's murky limits of obligation with a subject-relation that provides a motivating force for action and recognition in a public that stretches beyond political borders. Yet, the Global Citizen application does not articulate and harness a kind of innate, natural humanitarian reason in its call to global citizenship. Understanding what is at stake in the appeals of the Global Citizen application requires an analysis of how the humanitarian subject-position of 'global citizen' is called upon, organized, designed and governed within a popular humanitarian public that has become "'abstracted" or virtualized" and able to "gather together only by representative means" (Livingstone 2005, p. 22). If the coherence of national citizenship has always depended upon mediums and technologies of communication (Anderson 2006), the articulation of a humanitarian citizenship inclusive of all is evermore technological and mediated.

Designing Humanitarianism

The title of this chapter is a riff on Bruno Latour's paper, 'Give me a Laboratory and I will Raise the World' (1983), which was itself a modification of a statement famously attributed to ancient mathematician Archimedes. Depending on the source, it goes something like this: 'give me a place to stand 
[and a fulcrum or a lever] and I will move the world'. In his repurposing of the quotation, Latour was hinting at the way objects and sites of science, specifically laboratories, are 'fulcrums' engaged in political world-making, much like how Archimedes envisioned the earth to be an object of geometry. Technologies of all sorts behave in a similar way, because "technologies are embodiments of social and cultural structures" (Ito 2012, p. 3). Yet, they can still be taken up "in new ways by existing social groups and cultural categories" (p. 3), so the design of technologies may encourage certain uses, values, actions or behaviors, but they do not necessarily determine them. As political scientist, filmmaker and critical theorist Cynthia Weber argues, this is because the act of design is premised on a "language of things" "that enables the manipulation of technologies, materials, colors, forms and space to create different emotional and behavioral responses: efficiency, docility, desire, luxury, comfort, protection, fear, power, indifference" (Weber 2010, p. 10). Design is thus a technique of power, because the act of design works as an act of government, encouraging certain behaviors, beliefs and values and discouraging others. The power of design is witnessed in those mediums and technologies, like the iPhone application for Global Citizen, whose design can be connected to the formulation of the norms, structures and behaviors of citizenship, or to the virtues, truths and obligations of humanitarianism.

Cynthia Weber argues that in order to understand citizenship "we need to better understand how citizenship, citizens and those who are not (fully) counted as citizens are designed, re-designed and designated as beyond the 
scope of design" (Weber 2010, p. 9). But according to William Walters, to avoid ascribing too much agency to technologies and other products of design, we must also think of "technological objects as having their own political lives, and imagine research projects as the writing of their biographies" (Walters, unpublished manuscript). The Global Citizen application as a technological object is no different, with its political life and biography not only dependent upon the genealogy of global citizenship and humanitarianism, but also the emergence of mediated networks of online social media, and the prominence of market rationality in neoliberal times. In its design of global citizenship, the Global Citizen application presents an interface for humanitarianism that has its own 'political life'.

The Global Citizen Application as Tool and Interface

In its own words, the Global Citizen application is "a web and mobile platform to support the movement to end extreme poverty." 18 It is a "learning and action dashboard designed to ensure that people passionate about creating change have the information and resources they need to take action anytime, anywhere." Although in "launch phase," the application promises that eventually 'Global Citizens' will be able to volunteer through the application, "track

18 The quotations in this paragraph are from: 'Find out How Global Citizen Works and Vote for Us', Global Citizen, available at: <http://www.globalcitizen.org/Content/Contentaspx?id=8b5391a6-2834-4f06-b6db$64299 \mathrm{~b} 27 \mathrm{~b} 951>$, accessed 1 December 2012. Subsequent descriptions reference parts of the application accessible with registration at www.globalcitizen.org. 
consumer actions" and 'engage' politicians "with the role they can play creating change."

The website and mobile application have a simple, clean, black and white colour scheme with a large, red circle - taken from the 'o' in global - used as the application's logo. Below the sliding 'feature' photographs and videos on the main page, is a large black bar with a blank window asking for your email address with the text, "BECOME A GLOBAL CITIZEN. SIGN-UP." Below this bar, there are logo buttons for "elements of extreme poverty," including 'polio eradication', 'preventable and curable diseases', 'gender equality', 'food and hunger', 'primary education', 'fair trade', and more, with the last button signifying, ominously, that there are more 'elements of extreme poverty' "to come."

To register, potential global citizens are asked to create a profile by uploading a personal photograph and entering the kind of information most internet users have come to expect when registering for websites, including one's full name, resident country, postal code, email address, phone number, and a password, followed by a space to answer in one or two lines, "Why you're a Global Citizen?"

Moving through the mobile and online application as a newly-registered Global Citizen, participants are encouraged to earn rewards, which are stipulated as "opportunities to amplify your impact," by earning "activist points" "given on the basis of how complex different actions are." Example actions include earning one point for "watching a short video on an issue related to 
extreme poverty," earning one point for "sharing a video about extreme poverty on social networks," earning three points for "buying Fairtrade products," and earning ten points for "calling your representative in Congress," which is the highest-earning action. ${ }^{19}$

In addition to providing 'rewards', points accumulate to allow Global Citizens to earn 'badges' in the different areas, or elements, of extreme poverty. The badges recognize their recipients as 'advocates' for their area. Points, badges and titles are accumulated and displayed for personal reference on Global Citizen profile pages, but there is as of yet no way to see what is earned by others, or even to communicate with other Global Citizens. The badges, points and discursive style of the application instead create a 'high-five' culture of humanitarian cool. The only sense of community offered is in the bodies, smiles and gestures of those featured in the application's own videos and images communicative visuals that encourage self-recognition and belonging amongst a global community of virtuous, rockstar youth.

It is in the imagery and media of the Global Citizen application that this appeal to global citizenship is articulated. A young man runs through the desert, holding up a bright red flag like a cape, in designer jeans and sneakers with the capitalized text, "I AM \#GLOBALCITIZEN."20 The appeal to global citizenship is also embodied in the smiles and expressions of hopeful solidarity and the upward gazes of a sea of young people holding up their hands to form the 'o'

19 Sample actions listed here: 'About Us', Global Citizen, available at: < http://www.globalcitizen.org/AboutUs/AboutUs.aspx?typeId=15> , accessed 1 December 2012. 20 'About Us', Global Citizen, available at: http://www.globalcitizen.org/AboutUs/AboutUs.aspx?typeld=15, accessed 1 December 2012. 
shaped logo, alongside the text "JOIN US." 21 The invitation is in the videos produced by the Global Poverty Project and presented on the website and at the festival on September 29th, 2012 as calls to action. The emotionally resonant videos have Hollywood production values, incorporating soundtrack and editing flourishes to create the dramatic effect of movie trailers. When "it's you against hunger," and Global Citizens "will do whatever it takes," as in the case of the video for the UN World Food Programme USA, 22 'you' become the action hero the star of the show - in a voyeuristic call to stop hunger that is presented as affecting only destitute people in exotic and distant locales.

Yet, the Global Citizen application is remarkable not just for the exaltation of the humanitarian supporter or volunteer that Melissa Brough (2012) highlights in her work on humanitarian visual culture. Neither is it remarkable only for the perpetuation of the clichéd, paternalistic and pastoral appeal to aid the 'other' in its campaigns. Rather, the application itself is an interface of humanitarian citizenship with a political life and history, designed in a particular way to encourage contained public engagement. This is because the videos, graphic designs, and celebrity endorsements embedded in the application and festival do not simply act as an 'emotional interpreter' for the needs of others (Huliaras 2011, p. 299), but rather they actively create and frame humanitarian information (ie: hunger as a problem of aggressively cool food aid delivery) that demands particular solutions (the participation of you, the action-star).

21 'Home', Global Citizen, available at: <www.globalcitizen.org>, accessed 1 December 2012. 22 ' 1 Billion People in the World Are Hungry Today', Global Citizen, available at: < http://www.globalcitizen.org/Content/Contentaspx?id=96d047d2-8ccc-4d1e-b30aff28e14a5155>, accessed 1 December 2012. 
The application specifically delineates what solutions are required to rectify the humanitarian problems it presents. These solutions are limited to "more and better aid" directed by "our government," "fair trade" to ensure people can "work their way out of poverty," and "increased transparency and good governance." 23 The practices of global citizenship that are purported to bring about these ends are an awareness of popular NGOs that have partnered with the Global Poverty Project to provide content for the application, and a dedication to the publicity of the 'elements of extreme poverty' and their philanthropic solutions. Thus, the humanitarian public of the Global Citizen application is reduced to a mass of agents of publicity, where every 'share' and 'like' references back to the Global Citizen application as a brand, and back to the legitimacy of both liberal governance and the philanthropic, "non-profit industrial complex" (INCITE! 2009).

As chronicled in the first chapter, philanthropy is a form of altruism that is inherently tied to the birth of modern capitalism in alignment with Karl Polanyi's concept of the 'double transformation,' whereby the sustainability of capitalism requires markets to be "embedded in social and political institutions that regulate, moderate and legitimate market outcomes" (Brodie 2008, p. 31). The Global Citizen application is inseparable from this civil society, in how it is bound to capitalist economic processes, the naturalized desire for modern progress, and the governing rationality of calculation that places population as

23 'Australia Launches Global Citizen!', Global Citizen, available at: < http://www.globalcitizen.org/Content/Content.aspx?id=874d9ecc-5e 1a-449a-83020a81a617987b >, accessed 1 December 2012. 
its object. The design of the application situates individual Global Citizens as "the instrument, relay, or condition for obtaining something at the level of the population" (Foucault 2007, 42), with that something being the continuation and assurance of modern progress through the elimination of distant human suffering. As such, the individual who is told he can 'work his way out of poverty' thanks to the Fair Trade purchases of Global Citizens, is cast as an "entrepreneur for himself, being for himself his own capital, being for himself his own producer, being for himself his source of his earnings" (Foucault 2008, p. 296). This vision of human as entrepreneur of himself is bound up in the concept of civil society, "whose objective is its own self-limitation insofar as it is pegged to the specificity of economic processes" (p. 297). These economic processes require "a society oriented towards the market and a society that compensates for the effects of the market in the realm of values and existence" (p. 242). By naturalizing the structures and inequalities of global capitalism, the design of the Global Citizen application illustrates the historicity and particularity of humanitarian philanthropy as supportive of a civil society integral to the operation of capitalism.

Taken in conjunction with the emphasis the Global Citizen application places on Fair Trade, the application presents global social injustices as epistemic problems solvable through money and consumptive practices. Indeed, Global Citizens were informed following the festival that "as Global Citizens, we were all part of something incredible -we used the Festival platform to secure $\$ 1.3$ billion in funding commitments for projects helping to fight extreme 
poverty!" 24 What was never stipulated is how these 'funding commitments' differed from the ordinary budgets and project funds of the partner NGOs. Yet, the intrusion of the marketplace in the application and festival's calls to global citizenship is not limited to philanthropic rationality, and the human as entrepreneur of himself.

The Global Citizen application recasts citizenship as brand, not through philanthropic aims, but through a marketing of citizenship that utilizes the tropes of corporate capitalism and consumer advertising in the framing of humanitarian information. Everything from the red ' $\mathrm{o}$ ' logo to the design of the site, the branded merchandise for sale on Global Citizen's Facebook page and the Global Citizen videos with Hollywood production values, point back to the application as a brand. The application and its content may promote an awareness of global interdependencies, but this awareness is tied to the branded identity of the humanitarian global citizen, represented by the \#globalcitizen hashtag. With the hashtag, the \#globalcitizen, herself, becomes the brand. Both humanitarianism and citizenship could be considered to be "moral mythologies that used to be found outside of the consumer marketplace (Einstein 2012, p. 15), but as Roopali Mukherkee and Sarah Banet-Weiser attest, within the 'neoliberal moment' we find "our identities, rights, and ideologies are evermore precisely formulated within the logics of consumption and commodification" (2012, p. 9). Naomi Klein precipitated this movement, when she saw branding as "overtaking private and public spaces" as a "colonization" of "mental space"

\footnotetext{
${ }^{24}$ Mass email to Global Citizens from <www.globalcitizen.org>, 30 September 2012.
} 
(Einstein 2012). Thus, the act of declaring oneself as \#globalcitizen is a selfmediated proclamation of a branded, marketed humanitarianism where global civic action and humanitarian virtue are consumable and claimable products, represented by a t-shirt or a festival ticket. The hashtag becomes the stamp and brand of appropriate humanitarian virtue, and a simultaneous signifier of the branded public identity. However, the political implications of the design of the Global Citizen application are not limited to the infiltration of market rationality and branded identity. The application jeopardizes the potential of global justice in its very design.

The application's call to global citizenship is discursively structured as constitutive of acts "that present a sense of making a break, a rupture, a difference" (Rygiel 2011, p. 7), but the humanitarian actions enabled by the application and labeled as constitutive of global citizenship do not challenge the inequalities of global capitalism, power in the international order, or national citizenship structures. Rather, the solutions to the injustices of extreme poverty are accessible to privileged national citizens without risk, sacrifice or unrewarded effort. It is the banality of this effort and the game-like need for rewards - like tickets to a festival featuring one's favourite artists - that trivialize the realities of social injustices and the privileges of both national citizenship and access to technology and digital networks.

Much like the criticisms lobbed at Richard Falk's 'citizen pilgrim', the Global Citizen application enables citizenship and humanitarian virtue only amongst those able to access and use the online or mobile application and 
amongst those who presumably hold national citizenship in the countries within which the Global Poverty Project operates. Fulfilling Nancy Fraser's skepticism regarding the democratic inclusiveness of transnational publics, the Global Citizen is a first world citizen, with a reasonable amount of disposable income and disposable time, who is addressed by the application to become an agent of publicity for the \#globalcitizen brand. The glaring problem with such a limitation in the call to global citizenship is similar to other forms of commodity activism, for when "participation in the public sphere [is] shaped and secured by one's capacity to consume," it is "marginalized constituencies" that pay the heaviest price (Mukherjee \& Banet-Weiser 2012, p. 9). This is not only because the tools of public engagement are out of reach, but also the ability to raise issues is circumscribed in an activist paradigm that privileges consumption over critical discussion. Indeed, the same inequality is visible in all networked publics that intersect with market logic, because "areas and populations outside of this logic are subject to the tunnel effect: they virtually don't exist as far as the network, and hence, the dominant world economy is concerned" (Ito 2012, p. 28).

What this creates is a world of political and social engagement made up of Bruno Latour's 'plug-ins', which are those add-on items we are asked to download in order to view or use certain websites, or as he argues, in order "to activate what you were unable to see before" $(2005$, p. 207). Does the Global Citizen application activate humanitarian sentiment and engagement? For Latour, the metaphor of the plug-in illustrates that "being a fully competent 
actor now comes in discreet pellets, or to borrow from cyberspace, patches and applets," because "competence doesn't come in bulk any longer but literally in bits and bytes" (p.207). While we do not literally download our competencies like cyborgs, the Global Citizen application and the networked, traceable and self-promotional public life it is embedded in suggest that we can paradoxically collect and "make visible what was before only present virtually" (p. 207). such as the qualities of empathy, humanitarian sentiment, and activist politics.

\section{Conclusion: The Problem of Design}

It is easy to criticize the Global Citizen application and the neat, organized and governable vision of humanitarianism it presents. As an interface of global citizenship for a popular humanitarian public, the Global Citizen application provides a process of naturalization (registration), a common political community (humanity), common celebrations and holidays (the Global Citizen Festival), a common identity (\#globalcitizen), obligations (to end extreme poverty through philanthropy, foreign aid, good governance and fair trade consumptive practices), rights (to not suffer in extreme poverty), and even a flag (red, with the 'o' logo in white). But what is missing from the Global Citizen application and its vision of global citizenship is the ability to communicate and organize with fellow Global Citizens, including those to whom humanitarian efforts are directed. The circulation of discourse and the potential for selforganization are at the heart of the emancipatory potential of publics aimed at a political cause. To achieve this progressive end would require an ability for all 
Global Citizens to discuss, debate and determine the relevant global issues, the most important global injustices, what kinds of solutions and actions are needed, and, importantly, the ability to express anger and outrage as part of critical discourse. For, an application and festival that "shines a spotlight on the remarkable progress being made in the fight against poverty," 25 removes from the light what Manuel Castells (2012) identifies as the powerfully mobilizing emotions of anger and outrage over what remains to be done. This is not to say that Global Citizen makes anger impossible, because the application is only a frame for humanitarian engagement, and the framing process is "always incomplete" (Callon 1998, p. 252). Like all technologies, there is always the possibility of an "overflow" of unintended political effects (p. 252). So while anger and outrage over current global injustices is still possible as a reaction to the appeals of the Global Citizen application, it is optimistic acclaim that shines as the appropriate emotive response to this celebration of how far we have come.

Consequently, it is not a cosmopolitan ethic or humanitarian zeal that defines global citizenship, but the duty to "create these wider communities of discourse and to reduce the forms of unjust exclusion within them" (Linklater 1998, p. 34). This means engaging in humanitarian publics that are open to critical discourse without perceiving others as only recipients of aid, others as poor and needy or others as unable to speak for themselves, but others as bound up in a shared world of interdependencies. This view of the world is not

25 Mass email to Global Citizens from <www.globalcitizen.org $>30$ September 2012. 
reachable without political action and discourse that is "rooted in outrage, propelled by enthusiasm and motivated by hope" (Castells 2012, p. 15).

Nancy Fraser (2007) may have accurately delineated the emancipatory limits of transnational public discourse, but the ideal of critical, inclusive discourse premised on our interdependencies is valuable if only to provide a guidepost to strive for and a framework for critique. In this case, it is clear that for the board of the Global Poverty Project, the global citizen is not the student who campaigns for her university to divest from mining and extraction companies that negotiate unfair contracts overseas, nor is the global citizen concerned with how the securitization of national borders affects refugees and racialized immigrants at home. Instead, the Global Citizen application governs through humanitarian reason conditioned by exclusionary, neoliberal rationality and liberal governmentality. It designs a vision of humanitarian engagement founded on the moral imperative of human equality, but mobilized and enacted by an interface of citizenship that is dependent on patterns of consumption, a linear notion of progress and a picture of the virtuous Global Citizen as a selfaggrandizing subject and agent of digital publicity.

The implications of the application do not speak to a problem of a general turn towards the 'self in humanitarian publics, or a necessary limit of global citizenship, but rather the intellectual paucity and brand-oriented publicity of a particular design of humanitarian engagement. By presenting a tidy picture of the world, circumscribing critical discourse, and encouraging particular actions, the Global Citizen application and festival may be aimed at building a sustainable 
movement of youth to end 'extreme poverty', but this movement is being built within a dangerously cramped box. The question remains - what good can creep through the slats? 


\section{Conclusion}

New Designs, New Directions

By looking at what is public about humanitarianism, this thesis has argued that humanitarian appeals do not just govern the 'precarious' lives of others, but also those who are appealed to for support. This is because humanitarian reason is articulated, designed and made possible by mediums of communication, technological devices, texts, visuals and videos that bring suffering and needs into the light of the public, demanding particular responses. Humanitarian appeals depend on this process of 'making public', which leaves space for techniques of government in the shaping of address and response. As such, a language of publics allows for a more comprehensive understanding of how interfaces of humanitarian address and response work to grab and hold popular attention.

These popular humanitarian publics are transnational and amorphous, but held together by discourses and technologies that shape the possibilities of public engagement. The case study of the Global Citizen application shows how the design of humanitarian discourses and technologies matter, but trends that see branded, neoliberal rationality and liberal governmentality embedded in humanitarian appeals are not necessarily indicative of a switch from a natural, pure humanitarian altruism to a post-humanitarianism preoccupied with the 'self. Rather, the 'self' in humanitarianism is a constantly reconfigured, but 
always present, component of the moral obligation of humanitarianism and the virtue of being humanitarian. Consequently, the problem is not with the 'self' of contemporary humanitarianism but designs of humanitarian engagement that allow for an actualization of the self through patterns of consumption and branded publicity.

I have also argued that while the Global Citizen application mobilizes hope and optimism and encourages an awareness of the interdependencies and complexities of global inequalities, the application and festival simultaneously constrain the emancipatory potentials of global citizenship, social justice and humanitarian publics. This is not to say that humanitarian publics themselves are doomed to repeat a troublesome politics of pity because of the inherent need to massify the 'other' for publicity. This is also not to say that the malleable humanitarian optimism of youth necessarily leads to meddling and misinformed publics like those disparaged by Walter Lippmann (1927), or publics obsessed with the 'self in a 'politics of irony' as charged by Lilie Chouliaraki (2012). There has been no 'turn towards' the 'self in humanitarianism, but rather a thickening of the cultural and economic environment that privileges self-actualization through brands, publicity and consumption. This environment works to the detriment of more critical and reflective processes of self-actualization, such as the potential for self-fulfillment in recognizing and responding to our interdependencies, relationships and shared responsibilities in this world. ${ }^{26}$

${ }^{26}$ An alternative ethical framework for engaging with and responding to the needs of others starting from these assumptions is a feminist ethics of care. For how this could be conceptualized in international relations, see Joan Tronto's 'A Feminist Democratic Ethics of Care and Global 
It is in this respect that this thesis has attempted to skirt the temptation to chalk up the centrifuge of contemporary humanitarianism to a reductive dismissal of its irony or hypocrisy. Hypocrisy for Hannah Arendt is "the problem of the relationship between being and appearance" (Arendt 1963, p. 97), but she so wonderfully describes the problem of hypocrisy as possibly one of ambition, for the hypocrite not only wants "to appear virtuous before others, he wants to convince himself" (p. 99). In navigating modern virtue in neoliberal times, many of us are trying to convince ourselves that our actions, whether recycling plastic or purchasing local apples, do good in this world. But does the paucity of critique in cries of hypocrisy excuse the Global Citizen application from its troubling design?

In an age inescapably fused with performative technologies and the discourses of market logic and self-promotion, it is important to remember that critical politics can coexist with popular culture, since the problem is not a preoccupation with the 'self' in popular humanitarian publics, but in the specificities and affordances of the designs that govern them. In his description of art as a mediator, John Dewey illustrates that the design of texts, images, and devices can "break through the crust of conventionalized and routine consciousness... Poetry, the drama, the novel are proofs that the problem of presentation is not insoluble. Artists have always been the real purveyors of news, for it is not the outward happening itself which is new, but the kindling by

Care Workers: Citizenship and Responsibility', in R. Mahon, \& F. Robinson, Feminist Ethics and Social Policy: Towards a New Global Political Economy of Care. UBCPress, 2011; and Fiona Robinson's Globalizing Care: Ethics, Feminist Theory and International Relations. Westview Press, 1999. 
it of emotion, perception and appreciation" (Dewey 1925, p. 184). A kindling interface for popular humanitarian publics that starts from critical engagement with others as bound up in a shared, interdependent world has yet to be imagined and designed, but our networked cosmos keeps growing in breadth and complexity, providing cause for optimism. So while Global Citizen prepares to launch in Canada and the board of the Global Poverty Project continues to generate new options for participation and more polished calls to act, there remains potential in art and design to interrupt the expected and inspire new, diverse ways of being political, whether as a member of a public, a global citizen, or a humanitarian. 
Bibliography

Althusser, L. 1970. Ideology and Ideological Status Apparatuses. Retrieved 06 April 2012 from "Lenin and Philosophy" and Other Essays:

(http://www.marxists.org/reference/archive/althusser/1970/ideology.ht m\}

Anderson, B. 2006. Imagined Communities: Reflections on the Origin and Spread of Nationalism, New Edition. Brooklyn: Verso.

Arendt, H. 1958. The Human Condition. Chicago: Chicago University Press. -- 1963. On Revolution. New York: Viking Press.

Baubock, R. and V. Guiraudon. 2009. 'Introduction: Realignments of Citizenship: Reassessing Rights in the Age of Plural Memberships and Multi-level Governance', Citizenship Studies (13:5), p. 439-450

Barnett, C. 2008. 'Convening Publics: The Parasitical Spaces of Public Action', in Cox, K., M. Low and J. Robinson, eds., The SAGE Handbook of Political Geography. UK: Sage, 403-417.

Barnett, M. 2011. Empire of Humanity: A History of Humanitarianism. Ithica: Cornell University Press.

Barry, A. 2002. 'The Anti-Political Economy', Economy and Society (31:2), 268284.

-- 2001. 'Political Chemistry', in Political Machines: Governing a Technological Society, London: Athlone, 153-174.

Boltanski, L. 1999. Distant Suffering: Morality, Media and Politics. New York: Cambridge University Press.

Bishop, M. and M. Green. 2009. Philanthrocapitalism: How Giving Can Save the World. New York: Bloomsbury Press.

Borstein, E. 2009. 'The Impulse of Philanthropy.' Cultural Anthropology (24:4).

Brodie, J. 2008. 'The Social in Social Citizenship', in Engin Isin (ed.), Recasting the Social in Citizenship. Toronto: University of Toronto Press.

Brough, M. 2012. 'Fair Vanity: The Visual Culture of Humanitarianism in the Age of Commodity Activism', in Roopali Mukherjee and Sarah Banet-Weiser 
(eds.) Commodity Activism: Cultural Resistance in Neoliberal Times. New York: NYU Press.

Brown, C. 2000. 'Cosmopolitanism, World Citizenship and Global Civil Society', Critical Review of International Social and Political Philosophy (3:1), p. 726.

Butler, J. 2004. Precarious Life: The Power of Mourning and Violence. Verso.

Callon, M. 1998. 'An Essay on Framing and Overflowing: Economic Externalities REvisted by Sociology', in Callon, M., ed., The Laws of Markets. Oxford and Keele: Blackwell and the Sociological Review.

Castells, M. 2012. Networks of Outrage and Hope: Social movements in the Internet Age. Cambridge: Polity.

Chouliaraki, L. 2010.'Self-mediation: New Media and Citizenship', Discourse Studies (7:4), p. 227-242.

--2013. The Ironic Spectator: Solidarity in the Age of Post-Humanitarianism. Cambridge: Polity.

--2011. The Theatricality of Humanitarianism: A Critique of Celebrity Advocacy. Communication and Critical/Cultural Studies, 9:1, 1-21.

Colwell, C. 1997. 'Deleuze and Foucault: Series, Event, Genealogy.' Theory \& Event (1:2).

Cornell, T. and K. Lomas. 2002. Bread and Circuses: Euergetism and Municipal Patronage in Roman Italy. London: Routledge.

Dean, M. 1999. 'Pastoral Power, Police and Reason of State', Governmentality: Power and Rule in Modern Society. New York: Sage.

Dewey, J. 1925. The Public and its Problems, Swallow Press, 2006.

DiSalvo, C. 2009. 'Design and the Construction of Publics', Design Issues (25:1), 48-63.

Dower, N. 2000. 'The Idea of Global Citizenship - A Sympathetic Assessment', Global Society (14:4), p. 553-567.

Dunant, H. 1862. A Memory of Solferino. 1986 edition, Geneva: International Committee of the Red Cross.

Edkins, J. 2003. Humanitarianism, Humanity, Human. Journal of Human Rights, $2: 2,253-258$. 
Edwards, M. 2010. Small Change: Why Business Won't Save the World. BerettKoehler Publishers.

Einstein, M. 2012. Compassion Inc.: How Corporate America Blurs the Line Between What We Buy, Who We Are, and Those We Help. Berkeley: University of California Press.

Fassin, D. 2011. Humanitarian Reason: A Moral History of the Present. Berkeley: University of California Press.

-- 2010. 'Inequality of Lives, Hierarchies of Humanity: Moral Commitments and Ethical Dilemmas of Humanitarianism', in Feldman, I. and M. Ticktin, eds., In the Name of Humanity: The Government of Threat and Care. Durham: Duke University Press.

Feldman, I. and M. Ticktin, eds. 2010. In the Name of Humanity: The Government of Threat and Care. Durham: Duke University Press.

Foucault, M. 1991. Questions of Method. In B. e. (eds), The Foucault Effect. Chicago: Chicago University Press.

-- 2008. The Birth of Biopolitics: Lectures at the College de France, 1978-1979. Palgrave MacMillan.

-- 2007. Security, Territory, Population. Palgrave MacMillan.

-- 1998. Nietzsche, Genealogy, History. Vol. 2, in Essential Works of Michel Foucault 1954-1984, by J. Faubion.

Forsythe, D. 2009. 'Contemporary Humanitarianism: the Global and the Local', in Wilson, R. A. and R. D. Brown, eds., Humanitarianism and Suffering: The Mobilization of Empathy. New York: Cambridge University Press.

Furia, Peter. 2005. 'Global Citizenship, Anyone? Cosmopolitanism, Privilege and Public Opinion', Global Society (19:4), p. 331-359.

Fraser, N. 2007. 'Transnationalizing the Public Sphere: Legitimacy and Efficacy of Public Opinion in a Post-Westphalian World', European Institute for Progressive Cultural Policies. <http://eipcp.net/transversal/0605/fraser/en>, accessed 25 February 2013>

'Global Citizen Application'. (n.d.). The Global Poverty Project. Available at: \{www.globalcitizen.org\}, accessed 07 October 2012\}.

'Global Citizen Festival - Great Lawn, Central Park, September 29 2012'. (n.d.). The Global Poverty Project. Available at: $\{$ http://globalfestival.com\}, accessed 07 October 2012\}. 
'Global Poverty Project - Welcome'. (n.d.). The Global Poverty Project. Available at: \{http://www.globalpovertyproject.com/\}, accessed 07 October 2012\}.

Gross, R. A. 2003. Giving in America: From Charity to Philanthropy. In L. J. Friedman, \& M. D. McGarvie, Charity, Philanthropy and Civility in American History. Cambridge: Cambridge University Press.

Habermas, J. 1962. The Structural Transformation of the Public Sphere, Cambridge: MIT.

Held, V. 2007. The Ethics of Care: Personal, Political and Global. Oxford: Oxford University Press.

Hindess, B. 'The Liberal Government of Unfreedom', Alternatives: Global, Local, Political (26:2), 93-111.

Holmes, G. 2012. 'Biodiversity for Billionaires: Capitalism, Conservation and the Role of Philanthropy in Saving/Selling Nature', Development and Change (42:1), 185-203.

INCITE! Women of Color Against Violence. 2009. The Revolution Will Not Be Funded: Beyond the Non-Profit Industrial Complex. Cambridge: South End Press.

Isin, E. 2009. 'Citizenship in Flux: The Figure of the Activist Citizen', Subjectivity (29), p. 367-388.

Isin, E. and A. Lefebvre. 2005. "The Gift of Law: Greek Euergetism and Ottoman Waqf, European Journal of Social Theory (8:1), 5-23.

Ito, M. 2012. 'Introduction', in Varnelis, K., ed., Networked Publics. Boston: MIT Press.

Kurasawa, F. 2009a. 'Global Justice as Ethico-Political Labour and the Enactment of Critical Cosmopolitanism', Rethinking Marxism (21:1), 83-100.

- - 2009b 'A Message in a Bottle: Bearing Witness as a Mode of Ethico-Political Practice', Theory, Culture \& Society (26:1), 83-100.

Kidd, A. J. 1996. 'Philanthropy and the 'Social History Paradigm", Social History (21:2), 180-192.

Laqueur, T. 2009. Mourning, Pity and the Work of Narrative in the Making of 'Humanity', in Wilson, R. A. and R. D. Brown, eds., Humanitarianism and Suffering: The Mobilization of Empathy. New York: Cambridge University Press. 
Latour, B. and P. Weibel. 2005. Making Things Public: Atmospheres of Democracy. Cambridge: MIT Press.

Latour, B. 2005. Reassembling the Social: An Introduction to Actor-Network Theory. New York: Oxford University Press.

- - 1983. 'Give me a Laboratory and I Will Raise the World', in Knorr-Cetina, K.D. and M. Mulkay, eds., Science Observed. London: SAGE, 141-170.

Linklater, A. 1998. 'Cosmopolitan Citizenship', Citizenship Studies (2:1), p. 23-41.

Lippmann, W. 1927. The Phantom Public, Transactions Publications, 1993.

Livingstone, S., ed. 2005. Audiences and Publics: When Cultural Engagement Matters for the Public Sphere. Bristol: Intellect Ltd.

Loseke, D. R. 1997. 'The Whole Spirit of Modern Philanthropy: The Construction of the Idea of Charity, 1912-1992', Social Problems (44:4), 425-444.

Macklin, A. 2007. 'Who Is the Citizen's Other? Considering the Heft of Citizenship', Theoretical Inquiries in Law (8:2).

Malkki, L. 2010. 'Children, Humanity and the Infantalization of Peace', in Feldman, I. and M. Ticktin, eds., In the Name of Humanity: The Government of Threat and Care. Durham: Duke University Press.

Marres, N. 2005. 'Issues Spark a Public into Being: A Key but Often Forgotten Point of the Lippmann-Dewey Debate', in Latour, B. and P. Weibel, eds., Making Things Public: Atmospheres of Democracy. Cambridge: MIT Press.

Mukherjee, R. and S. Banet-Weiser, eds. 2012. Commodity Activism: Cultural Resistance in Neoliberal Times. New York: New York University Press.

Nussbaum, M. 1998. Cultivating Humanity: A Classical Defense of Reform in Liberal Education. Cambridge: Harvard University Press.

Paras, E. 2006. Foucault 2.0: Beyond Power and Knowledge. New York: Other Press.

Procacci, G. 1991. 'The Social Economy and the Government of Poverty', in Burchell, G., C. Gordon and P. Miller, eds., The Foucault Effect: Studies in Governmentality. Chicago: University of Chicago Press.

Rabinow, P., and N. Rose. 2006. 'Biopower Today', Biosocieties (1:2), 195-217.

Rieff, D. 2003. A Bed for the Night: Humanitarianism in Crisis. New York: Simon and Schuster. 
Rorty, R. 1993. Human Rights, Rationality, and Sentimentality, in Shute, S. and S. Hurley, eds., On Human Rights: The Oxford Amnesty Lectures. New York: Basic Books.

Rose, N. and P. Miller. 1992. 'Political Power Beyond the State: Problematics of Government', The British Journal of Sociology (43:2), p. 173-205.

Rygiel, K. 2008. 'The Securitized Citizen', in Engin Isin, ed., Recasting the Social in Citizenship. Toronto: University of Toronto Press.

Rygiel, K. 2011. 'Bordering Solidaries: Migrant Activism and the Politics of Movement and Camps at Calais', Citizenship Studies (15:1), p. 1-19.

Schattle, H. 2007. Practices of Global Citizenship. Ladham: Roman and Littlefield Publishers.

Sherman, N. 1997. Making a Necessity of Virtue: Aristotle and Kant on Virtue. UK: Cambridge University Press.

Smith, A. 1875. A Theory of Moral Sentiments. G. Bells \& Sons.

Street, J. 1997. Politics and Popular Culture. Temple University Press.

Suski, L. 2009. 'Children, Suffering and the Humanitarian Appeal', in Wilson, R. A. and R. D. Brown, eds., Humanitarianism and Suffering: The Mobilization of Empathy. New York: Cambridge University Press.

Swedberg, R. 1992. 'Review: Bread and Circuses by Paul Veyne', Acta Sociologica (35:3).

Tester, K. 2010. Humanitarianism and Modern Culture. University Park: Pennsylvania State University Press.

Huliaras, A. 2011. 'Conclusion: Making Sense of Transnational Celebrity Activism: Causes, Methods and Consequences,' in Tsaliki, L., C. Frangonikolopoulos and A. Huliaras. eds., Transnational Celebrity Activism in Global Politics: Changing the World? Bristol: Intellect.

Valverde, M. 1991. The Age of Light, Soap, and Water: Moral Reform in English Canada, 1885-1925. Toronto: McClelland \& Stewart.

Varnelis, K., ed. 2012. Networked Publics. Boston: MIT Press.

Veyne, P. 1990. Bread and Circuses: Historical Sociology and Political Pluralism. Allen Lane. 
Walters, W. 2011. 'Foucault and Frontiers: Notes on the Birth of the Humanitarian Border', in Bröckling, U., S. Krasmann and T. Lemke, eds, Governmentality: Current Issues and Future Challenges. New York: Routledge, 138-164.

- - n.d. 'Technological Objects, Security, and Politics: Opening Up the Black Box of 'Technology' in Critical Security Studies', Unpublished Manuscript.

Warner, M. 2002. Publics and Counterpublics, New York: Zone Books.

Weber, C. 2010. 'Introduction: Design and Citizenship', Citizenship Studies (14:1), p. 1-16.

Wilson, R. A. and R. D. Brown, eds. 2009. Humanitarianism and Suffering: The Mobilization of Empathy. New York: Cambridge University Press.

Winthrop, J. 1630. "A Model of Christian Charity." Religious Freedom. <http://religiousfreedom.lib.virginia.edu/sacred/charity.html> accessed April 16, 2012>.

Yrjola, R. 2011. "From Street into the World: Towards a Politicised Reading of Celebrity Humanitarianism." British Journal of Politics and International Relations (December). 